Andrews University

Digital Commons @ Andrews University

1972

\title{
A Comparison of Values in Black and White Children in the Upper, Middle and Lower Social Classes
}

Emmanuel Ola Atolagbe

Andrews University

Follow this and additional works at: https://digitalcommons.andrews.edu/theses

Part of the Education Commons, and the Ethnic Studies Commons

\section{Recommended Citation}

Atolagbe, Emmanuel Ola, "A Comparison of Values in Black and White Children in the Upper, Middle and Lower Social Classes" (1972). Master's Theses. 162.

https://dx.doi.org/10.32597/theses/162

https://digitalcommons.andrews.edu/theses/162

This Thesis is brought to you for free and open access by the Graduate Research at Digital Commons @ Andrews University. It has been accepted for inclusion in Master's Theses by an authorized administrator of Digital Commons @ Andrews University. For more information, please contact repository@andrews.edu. 


\title{
ABSTRACT OF GRADUATE STUDENT RESEARCH
}

Thesis

\author{
Andrews University
}

Department of Education

\author{
Title: A COMPARISON OF VALUES IN BLACK AND WHITE \\ CHILDREN IN THE UPPER, MIDDLE AND \\ LOWER SOCIAL CLASSES \\ Name of researcher: Emmanuel 01a Atolagbe \\ Name of faculty advisers: Dr. Conrad Reichert (chairman), \\ Dr. Wilfred Futcher, Dr. Natelkka Burre11 \\ Date completed: $\quad$ August 1972
}

Purpose of the Study

The purpose of the study was to (1) discover if the value system of blacks is different from the value system of whites, and (2) to determine if social class is a significant influencing factor in the shaping of values. 
Methods and Prowedures

Many studies have been conducted in which the values of blacks and whites of both sexes in the lower, middle and upper classes were examined. Schuster (1968) conducted a study in which the values

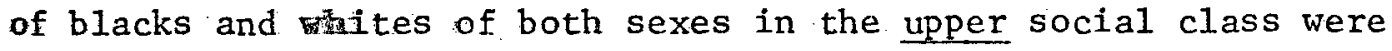
examined. Lot and Lott (1963) examined the values of both races and sexes in the middle and lower social classes. Parrilla (1971) studied the values of blacks and whites of both sexes in the lower class. The present study, however, examined blacks and whites of both sexes and Iooked at all three social classes simultaneously. A total of 165 pupils in grades 5 and 6 were examined. Wamer's criteria of social class were adhered to in deciding the social class of each pupil. A modified version of the AllportVernon-Lindzey Study of Values was used to assess the Aesthetic, Social, Politica1, Economic, Theoretical, and Religious values of the subjects.

Statistical Design

A $2 \times 2 \times 3$ (3 way) analysis of variance without replications, as designed by Crow, Davis, and Maxfield was used in the analysis of data in this study. Where significant interactions occurred, the t-test procedure was carried out on each level of interaction.

\section{Limitations}

There were sizable differences between many of the mean scores, but the statistical design used made it less likely that statistical 


\section{Conclusion}

The analyses of data'in this study indicated that

1. Race appears to be a determiner of valuẹs in some cases, but in other cases it does not seem influential.

2. Social class does not appear to be a statistically significant determinant of values.

3. Sex appears to be a determinant of values in some cases but not an important factor in other cases.

4. It appears that the differences within the races and classes are greater than the differences between the races and classes. As far as values are concerned, there is a large area of homogeneity between the races, classes and sexes. Human beings are more alike than they are different! 
Andrews University

School of Graduate Studies

A COMPARISON OF VALUES IN BLACK AND WHITE CHILDREN IN THE UPPER, MIDDLE AND LOWER SOCIAL CLASSES

A Thesis

Presented in Partial Fulfillment

of the Requirements for the Degree

Master of Arts

by

Emmanuel 01 a Atolagbe

August, 1972

Approval Goural Q Wuekert 

TABLE OF CONTENTS

Chapter

Page

I. INTRODUCTION .......................... 1

The problem .................. . . . 1

Purpose of the study... . . . . . . . . 4

II. REVIEW OF LITERATURE . . . . . . . . . . . 5

Definition of terms ............. . . 5

Origin of values............... . . 7

Related research . . . . . . . . . . 10

Summary of the 1iterature . . . . . . . . . . 14

Hypotheses . . . . . . . . . . . . . 14

III. METHODOLOGY . ................. 16

Population . . . . . . . . . . . . 16

Sample . . . . . . . . . . . . 16

The instrument. . . . . . . . . . . 21

Statistical design . . . . . . . . . . 23

Limitations . . . . . . . . . . . 23

IV. ANALYSIS OF DATA . . . . . . . . . . 25

Aesthetic value . . . . . . . . . . 25

Social value . . . . . . . . . . 27

Economic value . . . . . . . . . . . 29

Political value ............. . . 30

Religious value . . . . . . . . . . . 30

Theoretical value .............. 33

Summary ................ . . 34

V. CONCLUSIONS AND IMPLICATIONS . . . . . . 35

Summary . . . . . . . . . . 35

Limitations ............... . . 37

Conclusions . . . . . . . . . . 37

Implications . . . . . . . . . . . . 38 
TABLE OF CONTENTS (CONTINUED)

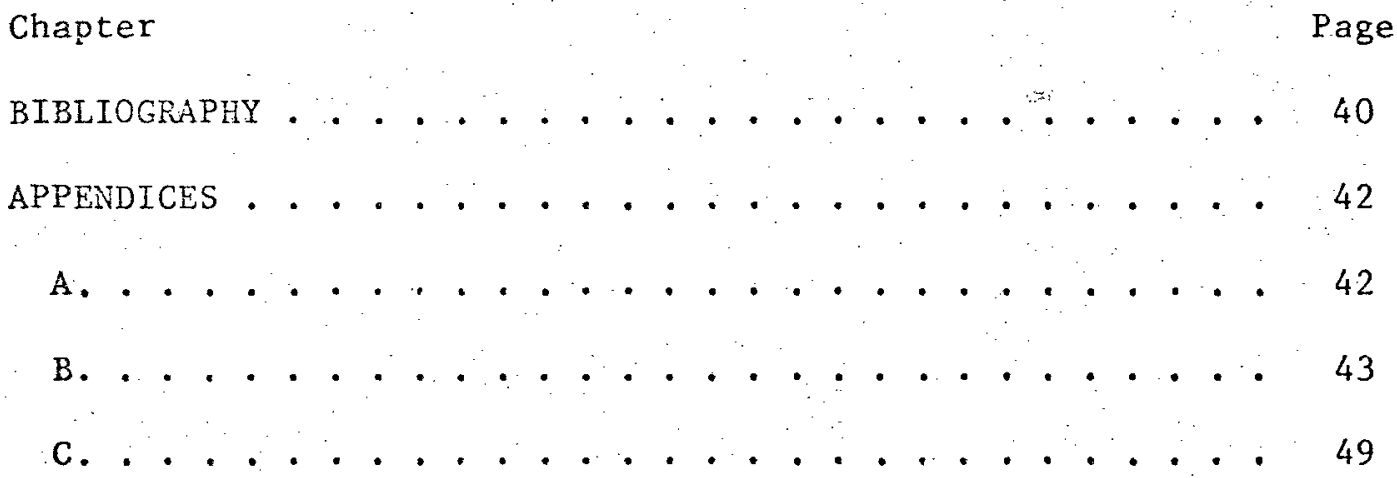




\section{LIST OF TABLES}

Table

Page

1. Distribution of Subjects in the Various

Comparisons Groups . . . . . . . . . . .

2. Analysis of Variance: The Effect of Social

Class, Race and Sex on Aesthetic Value ... . .

3. Mean Scores: Social Class, Race, and Sex

on Aesthetic Value . . . . . . . . . . .

4. Analysis of Variance: The Effect of Social

Class, Race, and Sex on Social Value ......

5. Mean Scores: The Effect of Social Class, Race, and Sex on Social Value . . . . . . .

6. Analysis of Variance: The Effect of Social

Class, Race, and Sex on Economic Value . . . . .

7. Mean Scores. The Effect of Social Class, Race, and Sex on the Economic Value . . . . . . .

8. Anaiysis of Variance: The Effect of Social

Class, Race, and Sex on Political Value . . .

9. Mean Scores: The Effect of Social Class, Race, and Sex on Political Value........ .

10. Analysis of Variance: The Effect of Social Class, Race, and Sex on Religious Value .........

11. Mean Scores: The Effect of Social Class, Race, and Sex on Religious Value :. . . . . . . . .

12. Analysis of Variance: The Effect of Social Class, Race, and Sex on Theoretical Value $\because . . \cdot \ldots \cdot$

13. Mean Scores: The Effect of Social Class, Race, and Sex on Theoretical Value .......... 


\section{CHAPTER I}

\section{INTRODUCTION}

\section{The Problem}

American children have been transported to school in the familiar yeliow buses, and at public expense for several decades. Yet, busing has become a divisive educational issue today. Educational psychologists are studying its effects on the achievement of children who ride the buses. Lawyers are examining constitutional implications. Beginning with the "Brown versus Board of Education" decision eighteen memorable years ago, the U. S. Supreme Court has almost invariably held that "de jure". segregation imposed by official action is inconsistent with the fourteenth amendment guarantee of equal protection of the laws.

Such decisions have resulted in mass busing of white and black pupils beyond neighborhood schools to create a more even racial mix. It has also produced a furor of protests by parents not only in cities like Richmond, Virginia but even in the northern cities such as Detroit, Michigan.

Anti-busing groups have mushroomed all over the country under different types of names. An anti-busing group led by a housewife recently marched some six hundred miles from Pontiac, Michigan to Washington. Politicians in an election year have capitalized 
on the issue. In short, busing in 1972 has become an American dilemma!

A recent Newsweek articie reflects the opinion of the laity:

The definitive analysis of the subject is, of course, the massive 1966 Federal study known as the Coleman report. A team of educational specialists headed by Johns Hopkins sociologist, James Coleman, found that such devices as smaller classes, newer books or more sophisticated facilities made little difference in the work of Negro children. But when black pupils attended schools in which the majority of the children were middle cliss whites, the blacks improved and the whites were unharmed. Coleman concluded that the determining factors in a classroon performance were social and economic background, not race . . (Newsweek, March 13, 1972, p. 22).

$\therefore \quad$ Since the Coleman report, many schools have had to integrate

partly because they cannot obtain federal subsidies unless they

fall in line with federal directives. Others have had to integrate

because of court decisions and pressures from civil-rights groups.

However, in the six years since the Coleman report appeared, continuiag studies of school achievement-including some that set out to disprove Coleman--have consistently supported its conclusions. These studies point to twin findings: on the one hand, that so called 'compensatory educatio:l' programs-which assume that pouring huge amounts of money into ghetto schools ill raise the achievement of segregated black children--have proved to be a dismal failure; on the other hand, that efforts to raise the schoolroom performance of poor, black children by exposing them to white middle class standards have usually been successfu] to a greater or lesser degree (Ibid.).

All of this then raises the questions: What are white middle class values? What are the values of "poor black children"? Are a person's values affected by his racial and economic backgrounds?

Does this mean that: the values of "poor black" children are qualitatively or quantitatively inferior to the values of white middle class children? And, basic to the problem, what are values? 
Dyer (1963, P. 35) stressed that as long as blacks are set apart socially they are bound to maintain a subculture more or less at variance with that of whites. Polarization along ethnic lines would continue to hamper the Iong cherished American dream of a nation forged and welded together by the very unity of its diversity. Hence a rapprochement is necessary between the races. He emphasized that group differences in scores between whites and blacks would persist over generations unless, of course, there was a cross-cultural dissemination of values and a removal of those social impediments that have often hampered the disadvantaged!

Project Head Start was one of the first parts of the Johnson administration's war on poverty. . . . The first relevant planning committee was established in November, 1964. Public announcement of the program was made in January, 1965. Head Start was operating on a nation-wide basis by the summer of 1965 . Several powerful ideas led to its establishment. First, there were thought to be problems in American education which might best be treated early in the child's educational career. A number of studies had shown that lower-class children in general, and minority group children . . . were educationally handicapped when they entered elementary school. These handicaps persisted throughout the children's schooling . . . they had substantially lower sel.f concept scores; they thought they had less control over their environment, and they had less 'need achievement' than their middle-class and majority counterparts (Smith and Bissel, 1970).

The notion has been that disadvantaged minority children must be exposed to white middle class cultures and values, and that a gradual assimilation of traditional middle class value systems will enable "culturally deprived" children to be better school achievers. Frequently, "de-culturalization" for Head Start Children begins with Ianguage usage. Middle class English diction is gradually 
and painstakingly substituted in place of the "ghetto dialect" which the children are more used to.

But this erosion of black values and self-concept has been decried by some. For instance, Charles E. Munat (1968) says, "Head Start has been cynically but not wholly inaccurately termed 'preparation rut'. . ."

\section{Purpose of the Study}

The purpose of the study was to (1) discover if the value system of blacks is different from the value system of whites, and (2) to determine if social class is a significant influencing factor in the shaping of values.

The results of this study are relevant to the purposes and methods of compensatory education. If it could be established that values of blacks and whites are on the whole rather identical, then perhaps the values of black children need not be changed so that they can be better achievers, a key function of compensatory education.

Further, if the value systems within each race are different between the social classes, then it could be concluded that value systems are affected by social status. 
CHAPTER IJ.

\section{REVIEW OF LITERATURE}

\section{Definition of Terms}

The literature reflects divergent opinions on the meaning and function of values in human society.

Webster's New Collegiate Dictionary (1961) defines value as

"the quality or fact of being excellent, useful or desirable." Aristotle is quoted as saying that "It is the things which are valuable and pleasant to a good man that are really valuable and pleasant (Maslow, 1959, p. 128).

Everett Hall (1952) authored a book entitled What is Value? He arrived at this conclusion: "One can not in correct language formulate an answer to the question, 'What is value' (p. 247)." Raths (1966) concurs:

The meaning of the term value is by no means clear in the social sciences or in philosophy. One can not find consensus for the definition. About the only agreement that emerges is that a value represents something important in human existence $(p, 9)$.

Nevertheless; professor Abraham Maslow (1959) has edited a work which might throw some light on this subject. First, he affirms that "the state of valuelessness has been variously described as anomie, amorality, anhedonia, rootlessness, emptiness, hopelessness, the lack of something to believe in and to be devoted to (p. vii)." 
In the same work, Dorothy Lee states that ". . by human values; by a value or a system of values, I mean the basis upon which an individual will choose one course rather than another, judged as better or wrong. We can speak about human values, but we can not know them directly. We infer them through their expression in behavior (p. 165)."

Raths (1966, p. 30) has developed a criterion of seven elements for determining a value. These seven elements are divided into three processes: choosing, prizing and acting.

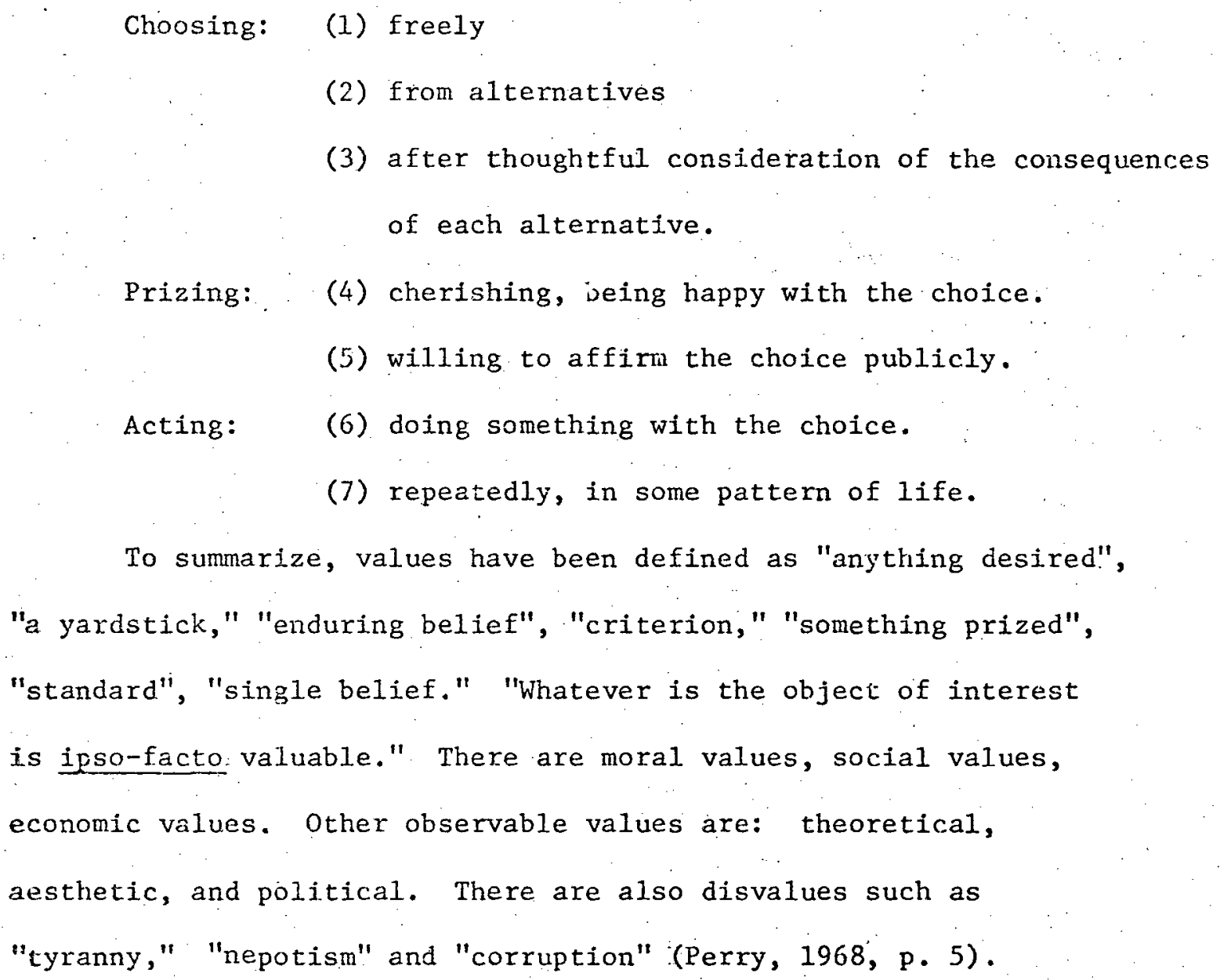




\section{Origin of Values}

Values are not transmitted through the genes and chromosomes, they are learned. Parents, friends, peers and even the pulpit are media of cultural and value diffusion. The earliest and most fundamental values come from the family circle and from close relationships with those who are admired and respected by the child (McGee, 1963, p. 4). The social scientist asserts that values arise out of the most satisfactory relationships between human needs and environmental conditions which involve and are dependent upon choice (Montagu, 1955, p. 153).

Havighurst (1962, p. 434) maintains that the infant begins to assimilate values through the process of rewards and punishments. Under this influence he soon begins to learn what is important and most prized. He learns through the responses of his parents-whether they encourage or deter, smile or scold, reward or punish him for his actions. Very soon, the child begins to emulate his parents and acquires their values as his very own. In addition, in the small world of the child, he is bound to be influenced by the values of his significant others, his neighbors, teachers, peers, religious leaders and adults within the community.

Many scudies have examined the value systems and development of self-concepts in both black and white children. Black psychologist Kenneth Clark (1957) puts it this way: 
- : In an effort to determine their racial preferences, we asked the children the following four questions: (1) "Give me the doll that you like to play with" or "the doll you like best." (2) "Give me the dol1 that is the nice do11." (3) "Give me the doll that looks bad." (4) "Give me the doll that is a nice color." The majority of these Negro children at each age indicate an unmistakable preference for the white doll and a rejection of the brown doll (p. 23).

Nevertheless, in a footnote Clark (1957, p. 23) concedes that "the childrea of six or seven showed some indication of an increased preference for the brown do11; even at this age, however, the majority of the Negro children still preferred the doll with the white skin color." In the same report he also states that "the tendency of older Jewish children to show less preference for Jewishness than younger Jewish children suggest that they have learned that Jews do not have a preferred status in the larger society, and that these children have accordingly modified their self-appraisal."

He further notes that

Studies of the development of racial awareness, racial identification, and racial preference in both Negro and white children thus present a consistent pattern. Learning about races and racial differences, learning one's own racial identity, learning which race is to be preferred and which rejected--all these are assimilaked by the child as part of the total pattern of ideas he acquires about himself and the society in which he lives... . Furtherwore, as the average child learns to evaluate these differences according to the standards of the society, he is at the same ime required to identify himself with one or another group. - : Some children as young as three years of age begin to express racial and religious attitudes similar to those held by adults in their society. The racial and religious attitudes of sixth-graders are more definite than the attitudes of high school students. Thereafter there is an increase in the intensity and complexity of these attitudes, until they become similar ... . to the prevailing attitudes held by the average adult American (Clark, 1957, pp. 23, 24).

Pettigrew (1964) concurs: 
Racial recognjtion in both white and Negro children appears by the third year and rapidly sharpens each year thereafter. of special significance is the tendency found in all these studies for Negro children to make racial distinctions, they frequently prefer white dolls and white friends, and they often identify themselves as white or show a tense reluctance to acknowledge that they are Negro. Moreover, young children of both races soon learn to assign realistically, poorer houses and less desirable roles to Negro dolls ( $p .23$ ).

It could well be, though, that what Pettigrew above refers to as the "tense reluctance to acknowledge that they are 'Negro'" is a calculated refusal by black children to identify themselves even at that age level with the white man's "Negro" with all of its value-laden connotations. For as Baldwin (1963) puts it: "You can only be destroyed by believing that you really are what the white world calls a 'nigger'. I tell you this because I love you, and please don't you ever forget it" (p. 54).

McCandless (1961, p. 466) declares that members of the lower social class tend to attach little importance to education. If parents were high school drop-outs themselves and didn't attach much importance to education, naturally the children might also be so inclined. Besides, the need for employment takes precedence over intellectual pursuits that may not necessarily guarantee a job, housing, and income commensurate with one's diploma. There are still other yardsticks and barriers that must be realistically weighed. Blacks in particular have no illusion about this. There is less motivation for educational pursuit. Minority groups are the last : : to be hired and the first to be fired in many instances. 


\section{Related Research}

Lott and Lott (1963, p. 6) conducted a study which explored the values and goals of black and white high school seniors in areas most relevant to their educational and vocational choices and plans. The instrument used was the Allport-Vernon-Lindzey Study of Values, which ranks a person's theoretical, religious, economic, political, social, and aesthetic values.

The data produced indicated that blacks scored significantly higher than whites on the theoretical scale, while whites scored significantly higher on the economic scale. There were no significant differences th respect to the religious, political, social, and esthetic values. The mean scores of the white males and females differed significantly on each of the six values, but there were no significant differences between the mean scores of the black males and black females on the theoretical, esthetic, and religious values. The black girls scored significantly higher than their white female counterparts on the theoretical scale. On the other hand black girls scored relatively lower than the white girls on the esthetic scale. With reference to both the theoretical and esthetic values, black females appeared to have scored in what the authors termed the male direction. But on the religious value the black females and males held close together, intermediate between the high mean score of the white females and the low mean score of the white males. In summary, the authors emphasized that "there are generally more similarities between the Negro and white high school seniors than differences"! 
Davis and Havighurst (1946) conducted a study in childrearing habits of black and white, middle and lower class - residents on the south side of Chicago.

One interesting observation made by the authors is relevant to this study.

There was seldom any doubt as to the proper classification. For the Negro group, the criteria were parallel to those for the classification of the white families, but shifted systematically because of restrictions on opportunity for Negroes in American society. For example, where the occupation of mail carrier would have suggested lower-class status for a white man, it suggested middle-class status for a Negro (p. 703).

The study indicated (p. 710) that significant differences emerged not along racial lines but between social classes. The same type of differences existed between middle and lower-class blacks as between middle and lower-class whites.

In conclusion the authors stated that "the striking thing about this study is the $t$ Negro and white middle class families are so much alike. The likenesses hold for such characteristics as number of children, ages of parents when married, as well as childrearing practices and expectations of children" (p. 708).

Somner and Killian (1954, p. 237) conducted a study, in which the subjects evaluated the behavior of a Negro. The authors explained that "alongside the structuring by the white of the role of the Negro exists the structuring by the Negro of the role of the Negro. When these roles are at variance, conflicts in the interactions between the races are apt to arise. To determine the extent of the divergence, the evaluations of ivegro subjects were contrasted with the evaluations of the prejudiced white subjects in the previous experiment." 
Somner and Killian concluded that blacks wanted blacks to be relatively more forward, aggressive, passionate, persistent and elegant. Whites on the other hand wanted Negroes to be relatively more witty, jovial, practical, quiet, and patient. The authors wanted the emphasis placed on relatively since the range was limited by the nature of the scale.

Eurthermore, the study seemed to indicate that blacks as a rule do not take pride in the values for which blacks are most appreciated by whites. Very few blacks, for example, accept loyalty, uncomplaining industry, and patience as having racial prestige value comparable to the importance attached to these traits by whites when they intend to speak favorably of blacks.

Nevertheless, Klinger and Veroff (1964, p. 903) indicated, in their study on the cross-cultural dimensions in stated moral values, that there are universal moral values which transcend and override customs, traditions and other cultural values. There are family traditions, there are also national customs and norms which may be peculiar to a people and country. Yet, undoubtedly, there are also norms and values which are similar and congruent to those existent elsewhere and are, as such, universal.

Variations that may exist within sccial classes were high1ighted in the work of Rettig and Passamanick (1961). They conducted a study on social or moral value structure among social classes with the conclusion that the relationship between severity of moral judgment and social or moral issues were curvilinear, reaching a peak in unskilled or upwardly mobile workers. Religious morality 
was high among the members of the lower social class. Severity of judgment on family morality issues varied within social classes hence the authors suggested that the religious and family dimensions of morality failed to relate curvilinearly to social class since they represent more deeply-embedded value orientations which are less pregnable to social change.

Rowland and Delcampo (1968) conducted and administered a children's version of the Allport-Vernon-Lindzey Study of Values to a 'culturally deprived' as opposed to a nonculturally deprived group of elementary school children. Except on the theoretical value where 'culturally deprived' males scored lower than the non-culturally deprived males, the scores of the races on the other values were similar. The authors concluded that "first we might wish to modify our belief in the difference of these children. They are perhaps different primarily in the sense that all individuals are different one from another. The differences among them. far exceeded the differences between them" (Rowland and Delcampo, 1968.)

Schuster (1968) conducted a study in which she sought to find if the value systems of black upper class children and white upper class children were different, using Rowland and Delcampo's instrument (the Elementary School Study of Values). Her sample contained 93 children, made up of 25 male and 28 female whites, and 19 male and 21 female blacks, all in Grades 1 to 3.

An analysis of variance showed that there were no significant differences between the means of the females of either race on any 
of the values and only one significant difference for the males. That disparity occurred between the Caucasian and Negro males in the. theoretical values. The study indicated a large area of homogeneity which appeared to transcend race.

Parrilla (1971) conducted a study among blacks and whites of both sexes in the lower-socio economic level, using the Rowland and Delcampo instrument. Her findings corroborated those of Schuster (1968) and Rowland and Delcampo (1968). There were no differences in the theoretical, economic, aesthetic and political values between the two races. The blacks, however, had a higher religious value than the whites $(\mathrm{p} .<.03)$ while the whites had a higher social value than the blacks $(p<.05)$. There were no significant interactions between race and sex for any of the six values studied.

\section{Summary of the Literature}

Various studies cited in this study seem to corroborate one another. The findings have been that there are few significant differences in values attributable to race and social class.

Differences that were indicated arose primarily in the sense that groups within races and classes were more likely to be different than groups between races and classes.

\section{Hypotheses}

In the light of the preceding review of literature, the following hypotheses were generated.

1. There are no differences in values attributable to race. 
2. There are no differences in values attributable to social class.

3. There are no differences in values attributable to sex.

The following chapter discusses the methods and procedures by which these hypotheses were tested. 
CHAPTER III

METHODOLOGY

\section{Population}

Benton Harbor, Berrien Springs, Eau Claire and Stevensville are small towns and villages in southwest Michigan containing numerous persons in all social levels and in both the black and white races. The population of these communities contains people such as medical doctors, dentists, lawyers, and managers of large industrial establishments. There is a university in Berrien Springs with a middle and upper class residential area surrounding it. Professionals such as magistrates, nurses, and proprietors of small business concerns live in the broad area. There are numerous farmers, factory workers, and shop attendants, also in the general community.

\section{Sample}

Warner's (1960) criteria of social class were adhered to in selecting the groups which were classified as the upper and middle social classes. The procedure adopted was as follows.

There are four status characteristics which are essential in social classification. They are: occupation, source of income, house type and dwelling area. Each of the four characteristics has a weight as listed below: 
Status Characteristic

Occupation

Source of Income

House type

Dwelling area
Weight

4

3

3.

$\therefore 2$

Each of these four status characteristics is rated across a seven-point scale which ranges from a rating of " 1 ", very high status value, to "7", very low status value. These ratings are as follows.

Source of Income

Inherited wealth

Earned wealth

Profits and fees

Salary

Wages

Private relief

Public relief and non-respectable home

House type

Excellent houses

Very good houses

Good houses

Average houses

Fair houses

Poor houses

Very poor houses

\section{Rating}

1

2

3

4

5

6

7

Rating

1

2

3

4

5

6

7 
Dwelling area

Very high, restricted suburbs

High, the better suburbs

Above average areas, apartments

Average, no deterioration

Below average, beginning to

deteriorate

Low; considerably deteriorated, semi-slum

Very low; slum

Occupation

Professionals and proprietors of large businesses

Semi-professionals and smaller

officials of large businesses

Clerks and kindred workers

Skilled workers

Proprietors of small businesses

Semi-skilled workers

Unskilled workers
Rating

1

- 2

3.

4

5

6

7

Rating

For example, if the ratings for an individual are $3,3,2$, and

3, for occupation, source of income, house type, and dwelling area respectively, the weighted total is secured as follows: 
Status

Characteristic

Occupation

Weight Rating Product

Source of income

4

3

12

3

3

9

House type

3

2

6

Dwelling area

2

3

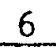

Weighted Total =

33

The individual's social class is then determined by locating his social class equivalent according to the following classification.

Weighted Total

of Ratings

12-17

$18-22$

23-24

$25-33$

$34-37$

$38-50$

$51-53$

$54-62$

63-66

$67-69$

$70-84$

\section{Social Class Equivalents}

Upper class

Upper class probably, may be middle upper class

Indeterminate: either upper or upper middle class

Upper middle class

Indeterminate; either upper middle, or lower middle.

class

Lower middle class

Indeterminate: either lower-middle or upper lower class Upper lower class

Indeterminate: either upper lower or middle lower class

Thus a proprietor of a large business concern who has inherited his vealth and lives in a large house in an exclusive restricted suburb would fall, within the upper-upper class category. 
Conversely, an unskilled worker on wages and living in a small house in good condition in a semi-slum area belongs to a middle-lower class.

The three social classifications used in this study--lower, middle, and upper classes-represent the broad spectrum of the individual social classes, and no attempt is made to study the various subdivisions within each class.

Twenty-five black and 25 white subjects in the upper class were obtained from the Lakeshore Elementary School, Stevensville. They were all in grade five. There were 12 boys and 13 girls in each racial group.

The middle class subjects consisted of 25 blacks and 25 whites who were obtained from Sylvester Elementary School, Berrien Springs and Lybrook Elementary Schoo1, Eau Claire. These subjects were in grades 5 and 6.

Parrilla's data (1971) for 65 lower class children in grades 5 and 6--36 blacks, 16 males and 20 females; 29 white, 15 males and 14 females-was used for the lower class in this study. The distribution of subjects in each social class, race and sex is indicated below. 
TABLE 1

\section{DISTRIBUTION OF SUBJECTS IN THE VARIOUS \\ COMPARISONS GROUPS}

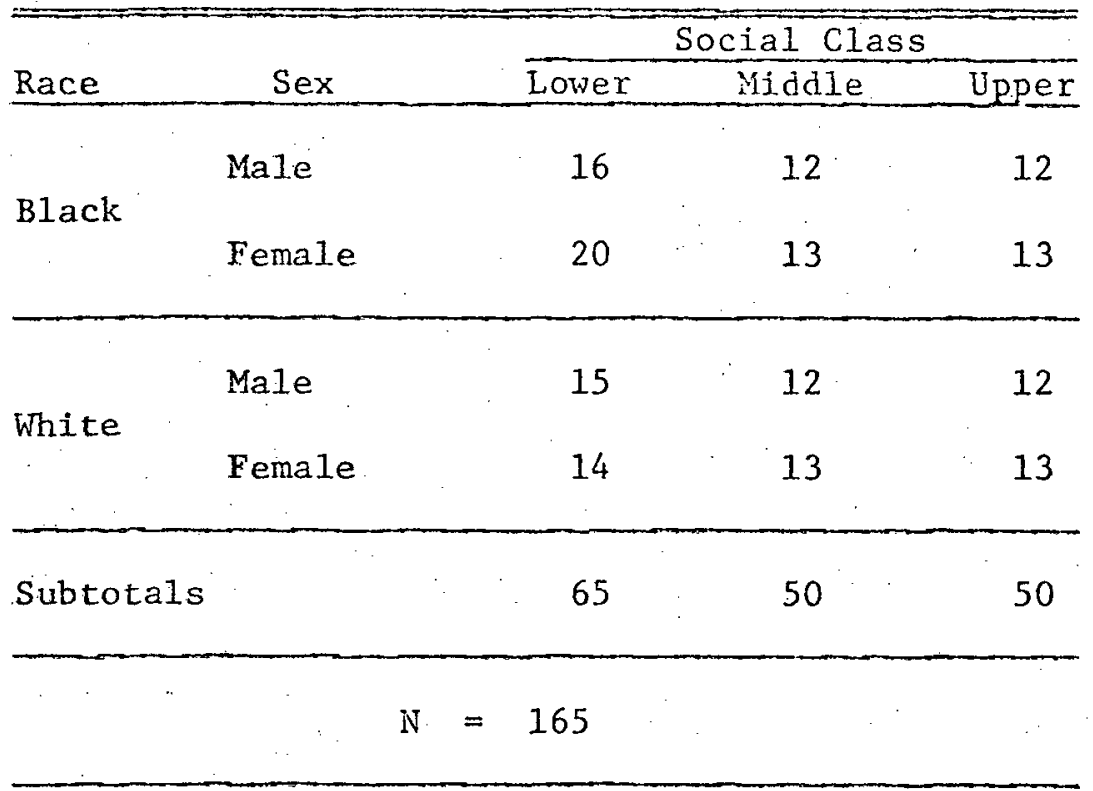

In obtaining the sample for this study, the whole population in the classroom took the test. The only exception was in the Sylvester Elementary School, Berrien Springs where the principal, using Warner's criteria of social class, selected twenty middle class whites from Grade five. All of the blacks in the fifth grade at Sylvester School participated in the study. The tests were taken in the classrooms at Lakeshore Elementary School, Stevensville, and at Lybrook Elementary Schoo1, Eau Claire. The test was taken in the gymnasium at Sylvester Elementary School, Berrien Springs.

\section{The Instrument}

The instrument used to test the hypotheses was the Elementary School Study of Values (ESSOV). This was a modified version of the Allport-Vernon-Lindzey Study of Values which was developed by Dr. Rowland. 
Rowland and Delcampo (1968) state that the ESSOV has a test-retest reliability of .77 and an internal consistency index of .72. A letter was sent to Dr. Rowland requesting that he explain how the validity of the ESSOV was derived. (See Appendix). The letter was unanswered at the time of this writing.

The ESSOV was developed to assess in children the same values-aesthetic, economic, social, political, religious, and theoretical-which the Allport-Vernon-Lindzey Study of Values assesses in adults. These values are described below.

Theoretical value refers to a dominant interest in the discovery of truth, in ordering and systematizing knowledge, through observation and reasoning.

Economic value denotes interest in what is useful, in the practical affairs of business, and in the accumulation of wealth.

Aesthetic value denotes interest in form and harmony, in grace and symmetry, and in the artistic episodes of life, which are regarded as a procession of events in which impression is enjoyed for its own sake.

Social value is characterized by love of people, altruism, or philanthropy, kindness, sympathy and unselfishness.

Political value involves a primary interest in power, competition, influence, and renown (in any vocation, not necessarily politics.)

Religious value concerns interest in the mystical and in comprehending the unity of the cosmos and men's relation to it (A11port, Vernon, Lindzey, 1960). 


\section{Statistical Design}

The Parrilla data consisted of mean scores only, therefore. the three-way analysis of variance without replications as discussed by Crow, Davis, and Maxfield (1960, pp. 109-146) was used.

The effects of the independent variables (1) race, (2) sex, and (3) social class were analyzed by use of the three-way analysis of variance on $2 \times 2 \times 3$ levels. Six separate analyses were carried out on the dependent variables:

1. Aesthetic

2. Social

3. Economic

4.. Political

5. Religious

6. Theoretical

Where significant interactions occurred, the t-test procedure was carried out to analyze the differences between the mean scores at each level of the groups involved in the interaction.

\section{Limitations}

One whole classroom each from the Lakeshore and Lybrook Schools was tested. However, in the Sylvester Elementary School, Berrien Springs, the Principal selected the subjects: It should be noted here that none of the classrooms was selected on a random basis, and this may create some limitations on the interpretations of the data in the study.

Also, there were sizable differences between many of the mean scores, but the statistical design used made it less likely that 
statistical significance would be achieved. Hence, one may not feel overly confident that there are no differences between the groups compared. For this reason it is felt that an orthogonal statistical design be used in further study of the topic researched. 
CHAPTER IV

ANALYSIS OF. DATA

A three-way analysis of variance without replications was used to test for statistical significance. This chapter presents the data on each value.

\section{Aesthetic Value}

The data on aesthetic value (Tables 2 and 3) did not indicate any significant differences between the three social classes. There were no significant differences between the races, nor were there any significant differences between the sexes, A significant difference in the interaction, between race and sex, was found. The t-test procedure was carried out on each level of race and sex, but no statistical significance was indicated.

As has been previously pointed out, aesthetic value denotes interest in form and harmony, in grace and symmetry, and in the artistic episodes of 1 ife, which are regarded as a procession of events in which impression is enjoyed for its own sake. In this study, no significant difference in aesthetic value was found between the social classes, races and sexes.

It must be borne in mind, however, that Davis and Havighurst (1946) reached a similar conclusion. Their study compared two social classes, middle and upper; and two races, black and white. They 
TABLE 2

ANALYSIS OF VARIANCE

THE EFFECT OF SOCIAL CLASS, RACE AND SEX ON AESTHETIC VALUE

\begin{tabular}{lccccc}
\hline Source & SS & df & MS & F & P \\
\hline Social Class & 6.02 & 2 & 3.01 & 8.36 & NS \\
Race & .59 & 1 & .59 & 1.64 & NS \\
Sex & 2.41 & 1 & 2.41 & 6.69 & NS \\
Social Class and Race & 1.05 & 2 & .53 & 1.47 & NS \\
Social Class and Sex & 11.93 & 2 & 5.97 & 16.58 & NS \\
Race and Sex & 6.84 & 1 & 6.84 & 19.00 & .05 \\
\hline Residual & .72 & 2 & .36 & -1 & - \\
\hline Total & 29.56 & 11 & -1 & -1 & - \\
\hline
\end{tabular}

TABLE 3

MEAN SCORES

SOCIAL CLASS, RACE, AND SEX ON AESTHETIC VALUE

\begin{tabular}{lllll}
\hline & & \multicolumn{3}{c}{ Social Class } \\
\cline { 3 - 5 } Race & Sex & Lower & Middle & Upper \\
\hline \multirow{2}{*}{ Black } & Fale & 14.06 & 17.00 & 14.41 \\
& Female & 16.10 & 13.61 & 13.92 \\
\hline \multirow{2}{*}{ White } & Male & 12.53 & 16.16 & 13.58 \\
& Female & 17.57 & 17.00 & 14.92 \\
\hline
\end{tabular}


concluded that "the striking thing about this study is that Negro and white middle class families are so much alike. The likenesses. hold for such characteristics as number of children, ages of parents when married, as well as child rearing practices and expectations of children". (p. 708).

Rowland and Delcampo's study (1968) also found no significant differences between black and white children on aesthetic value.

Schuster (1968) found no significant difference between white and black children in the upper class on aesthetic value.

Parrilla (1971) did not find any significant differences between black and white children in the lower class on aesthetic value. The data seem to indicate that there is little difference between the social classes, races and sexes in aesthetic value.

\section{Social Value}

The analyses of the effects of social class and sex on social value (Tables 4 and 5 ) did not indicate any significant differences. Neither were there any significant differences as a result of the interaction between classes, races and sexes. There were, however, differences attributable to race $(p<.05)$.

Social value is characterized by love of people, altruism or philanthropy, kindness, sympathy and unselfishness. This study indicated a significant difference in social value between the races $(p<.05)$, but significant differences between the social classes and sexes was not indicated. Within the lower class, the blacks scored significantly lower than the whites. 
TABLE 4

ANALYSIS OF VARIANCE

THE EFFECT OF SOCIAL CLASS, RACE, AND SEX ON SOCIAL VALUE

\begin{tabular}{lccccc}
\hline Source & SS & df & MS & F & P \\
\hline Social Class & 4.21 & 2 & .75 & 8.33 & NS \\
Race & .82 & 1 & 4.15 & 46.11 & .05 \\
Sex & 1.20 & 1 & 1.20 & 13.33 & NS \\
Social Class and Race & 3.10 & 2 & 1.36 & 15.11 & NS \\
Social Class and Sex & 1.51 & 2 & .76 & 8.44 & NS \\
Race and Sex & .15 & 1 & .15 & 1.67 & NS \\
\hline Residual & .17 & 2 & .09 & -1 & - \\
\hline Total & 11.16 & 11 & -16 & -1 & - \\
\hline
\end{tabular}

TABLE 5

MEAN SCORES

THE EFFECT OF SOCIAL CLASS, RACE, AND SEX ON SOCIAL VALUE

\begin{tabular}{ccccc}
\hline \multirow{2}{*}{ Race } & Sex & Lower & Social Class \\
\hline \multirow{2}{*}{ Black } & Male & 13.00 & 13.83 & 13.58 \\
& Female & 14.90 & 14.46 & 13.62 \\
\hline \multirow{2}{*}{ White } & Male & 15.40 & 13.58 & 13.67 \\
& Female & 16.42 & 14.38 & 13.08 \\
\hline
\end{tabular}


These results agree with the findings of Parrilla (1971) in which blacks scored lower than whites.

\section{Economic Value}

Economic value denotes interest in what is useful, in the practical affairs of business, and in the accumulation of wealth. The data in Tables 6 and 7 indicate that the economic value of the subjects was not affected by their social class, race or sex.

This is in agreement with Rowland and Delcampo (1968), . Schuster, (1968), and Parrilla (1971). These researchers used the same instrument in their studies and also found no significant differences between the races and sexes on economic value.

\section{TABLE 6}

ANALYSIS OF VARIANCE

THE EFFECT OF SOCIAL CLASS, RACE, AND SEX ON ECONOMIC VALUE

\begin{tabular}{lcccccc}
\hline Source & SS & df & MS & F & $P$ \\
\hline Social Class & 2.93 & 2 & 1.47 & 1.00 & NS \\
Race & .17 & 1 & .17 & .12 & NS \\
Sex & 3.18 & 1 & 3.18 & 2.16 & NS \\
Social Class and Race & .80 & 2 & .42 & .29 & NS \\
Social Class and Sex & 1.66 & 2 & .83 & .56 & NS \\
Race and Sex & 1.31 & 1 & 1.31 & .89 & NS \\
\hline Residual & 2.93 & 2 & 1.47 & -- & - \\
\hline Total & 12.98 & 11 & -1 & - & -1 \\
\hline
\end{tabular}


TABLE 7

MEAN SCORES

THE EFFECT OF SOCIAL CLASS, RACE, AND SEX

ON THE ECONOMIC VALUE

\begin{tabular}{|c|c|c|c|c|}
\hline \multirow[b]{2}{*}{ Race } & \multirow[b]{2}{*}{ Sex } & \multicolumn{3}{|c|}{ Social Class } \\
\hline & & Lower & Middle & Upper \\
\hline \multirow{2}{*}{ Black } & Male & 16.31 & 15.67 & 15.08 \\
\hline & Eemale & 15.75 & 18.38 & 18.00 \\
\hline \multirow{2}{*}{ White } & Male & 16.00 & 17.08 & 16.67 \\
\hline & Female & 16.78 & 18.23 & 15.85 \\
\hline
\end{tabular}

\section{Political Value}

As has been pointed out, political value denotes a primary

interest in power, competition, influence, and renown (in any vocation, not necessarily politics).

The data shown in Tables 8 and 9 indicate that the political value of the subjects was not affected by their social class, race or sex.

\section{Religious Value}

Tables 10 and 11 indicate that there were no statistically significant differences in religious value due to social class and sex. The interactions between class, race and sex were also not statistically significant. There was a significant difference, however, between the races $(p<.05)$ in which blacks scored higher than whites. This finding agrees with the results of the Parrilla study (Parri11a, 1971). 
TABLE 8

ANALYSIS OF VARIANCE

THE EFFECT OF SOCIAL CLASS, RACE, AND SEX ON POLITICAL VALUE

\begin{tabular}{|c|c|c|c|c|c|}
\hline Source & SS & $\mathrm{df}$ & MS & $\mathrm{F}$ & $\mathrm{P}$ \\
\hline Social Class & 5.46 & 2 & 2.73 & 1.76 & NS \\
\hline Race & .12 & 1 & .12 & .08 & NS \\
\hline Sex & 3.16 & 1 & 3.16 & 2.05 & NS \\
\hline Socia1 Class and Race & 4.12 & 2 & 1.42 & .92 & NS \\
\hline Social Class and Sex & 8.33 & 2 & 4.17 & .95 & NS \\
\hline Race and Sex & .52 & 1 & .52 & .34 & NS \\
\hline $\begin{array}{c}\text { Residual } \\
\end{array}$ & 3.10 & 2 & 1.55 & -- & $-\div$ \\
\hline Tota1 & 24.81 & 11 & - & - & - \\
\hline
\end{tabular}

TABLE 9

MEAN SCORES

THE EFFECT OF SOCIAI. CLASS, RACE, AND SEX ON POLITICAL VALUE

\begin{tabular}{|c|c|c|c|c|}
\hline \multirow[b]{2}{*}{ Race } & \multirow[b]{2}{*}{ Sex } & \multicolumn{3}{|c|}{ Social class } \\
\hline & & Lower & Middle & Upper \\
\hline \multirow{2}{*}{ Black } & Male & 15.37 & 12.83 & 13.92 \\
\hline & Female & 11.15 & 14.53 & 14.62 \\
\hline \multirow{2}{*}{ White } & Male & 15.46 & 12.66 & 14.67 \\
\hline & Female & 12.92 & 11.07 & 14.46 \\
\hline
\end{tabular}


TABLE 10

ANALYSIS OF VARIANCE

THE EFFECT OF SOCIAL CLASS, RACE, AND SEX ON RELIGIOUS VALUE

\begin{tabular}{lccccc}
\hline Source & SS & df & MS & F & P \\
\hline Social Class & 2.15 & 2 & 1.08 & 2.45 & NS \\
Race & 24.31 & 1 & 24.31 & 55.25 & .05 \\
Sex & 1.01 & 1 & 1.01 & 2.30 & NS \\
Social Class and Race & .09 & 2 & .05 & .11 & NS \\
Social Class and Sex & 6.97 & 2 & 3.49 & 7.93 & NS \\
Race and Sex & 1.73 & 1 & 1.73 & 3.93 & NS \\
\hline Residual & .87 & 2 & .44 & -1 & - \\
\hline Total & 37.13 & 11 & -1 & -1 & - \\
\hline
\end{tabular}

TABLE 11

MEAN SCORES

THE EFFECT OF SOCIAL CLASS, RACE, AND SEX ON RELIGIOUS VALUE

\begin{tabular}{lllll}
\hline \multirow{3}{*}{ Race } & Sex & \multicolumn{3}{c}{ Social Class } \\
\cline { 3 - 5 } Black & Male & 16.81 & 17.16 & 19.42 \\
& Female & 20.50 & 18.53 & 18.38 \\
\hline \multirow{2}{*}{ White } & Nale & 14.80 & 15.66 & 16.67 \\
& Female & 16.35 & 14.62 & 15.62 \\
\hline
\end{tabular}


Theoretical Value

The data in Tables 12 and 13 indicate that the theoretical value of the subjects was not affected by their social class, race or sex.

Schuster (1968), Rowland and Delcampo (1968) found significant differences relative to this value, while Parrilla did not.

TABLE 12

ANALYSIS OF VARIANCE

THE EFFECT OF SOCIAL CLASS, RACE, AND SEX ON THEORETICAL VALUE

\begin{tabular}{|c|c|c|c|c|c|}
\hline Source & SS & $\mathrm{df}$ & MS & $\mathrm{F}$ & $\mathrm{P}$ \\
\hline Social Class & 8.39 & 2 & 4.20 & 2.70 & NS \\
\hline Race & .01 & 1 & .01 & .01 & NS \\
\hline Sex & 15.44 & 1 & 15.44 & 9.79 & NS \\
\hline Social Class and Race & 21.86 & 2 & 10.93 & 6.87 & NS \\
\hline Socjal Class and Sex & 6.40 & 2 & 3.20 & 2.01 & NS \\
\hline Race and Sex & .00 & 1 & .00 & .00 & NS \\
\hline Residual & 3.18 & 2 & 1.59 & -- & - \\
\hline Total & 55.28 & 11 & - & -- & - \\
\hline
\end{tabular}


TABLE 13

MEAN SCORES

THE EFFECT OF SOCIAL CLASS, RACE, AND SEX ON THEORETICAL VALUE

\begin{tabular}{|c|c|c|c|c|}
\hline \multirow[b]{2}{*}{ Race } & \multirow[b]{2}{*}{ Sex } & \multicolumn{3}{|c|}{ Social Class } \\
\hline & & Lower & Middle & Upper \\
\hline \multirow{2}{*}{ Blacks } & Male & 14.43 & 17.83 & 13.58 \\
\hline & Female & 11.60 & 15.23 & 12.08 \\
\hline \multirow{2}{*}{ Whites } & Male & 15.80 & 13.83 & 16.25 \\
\hline & Female & 10.14 & 12.83 & 16.23 \\
\hline
\end{tabular}

Summary

The analysis of the data in this study indicated no differences between social classes, races, and sexes on the aesthetic value, theoretical value, political value, and economic value. There were significant differences, however, between blacks and whites on social value and religious value. The blacks scored significantly lower than whites on social value, while the whites scores significantly lower than the blacks on the religious value. These findings were in agreement with earlier studies cited (Davis and Havighurst, 1946; Lott and Lott, 196.3; Rowland and Delcampo, 1968, Schuster, 1968; and Parrilla, 1971). 


\section{CHAPTER V}

\section{CONCLUSIONS AND IMPLICATIONS}

\section{Summary}

With the advent of racial integration in the nation's classrooms, many studies have revolved around the question of racial or cultural factors which might affect the education of children. In this study, the values of blacks and whites in both sexes; lower, middle, and upper social classes were examined.

It was the purpose of this study to

1. determine if the value system of blacks is different from the value system of whites.

2. discover if social class is a significant influencing factor in the shaping of values.

If the value systems within each race are different between the social classes, then it might be concluded that value systems are affected by social status.

The following hypotheses guided the study.

1. There are no differences in values attributable to race.

2. There are no differences in values attributable to social class.

3. There are no differences in values attributable to sex.

The analysis of the data in this study indicated no differences between social classes, races and sexes on the aesthetic value, 
theoretical value, political. value, and economic value. There were significant differences, however, between blacks and whites on social value and religious value. The blacks scored significantly lower than whites on social value, while the whites scored significantly lower than blacks on the religious value.

The first hypothesis, that there are no differences in value attributable to race, was partly upheld and partly rejected. There were no statistically significant differences between biacks and whites for the aesthetic, theoretical, economic, and political values. But the differences were statistically significant between the races for the social value and religious value.

The second hypothesis, that there are no differences in value attributable to social class, was upheld by this study. This study indicated no statistically significant differences between the upper, middle, and lower social classes.

The third hypothesis, that there are no differences in value attributable to sex, was upheld for all six values--aesthetic, social, economic, political, religious and theoretical.

The present data corroborates the findings of the previous studies. These studies were conducted on blacks and whites, of both sexes, in the upper class by Schuster (1968), in the lower and middle classes by Lott and Lott (1963), and in the lower class by Parrilla (1971). The present study, however, examined blacks and whites of both sexes and looked at all three social classes simultaneously. 


\section{Limitations}

One whole classroom each from the Lakeshore and Lybrook Schools was tested. However, in the Sylvester Elementary School, Berrien Springs, the principal selected the subjects. It should be noted that none of the individuals or classrooms was randomly selected, and this may create some limitations on the interpretations of the data in the study.

Also, there were sizable differences between many of the mean scores, but the statistical desjgn used made it less likely that statistical significance would be achieved. Hence, one may not feel overly confident that there are no differences between the groups compared. For this reason it is felt that an orthogonal statistical design be used in further study of the topic researched.

\section{Conclusions}

This study examined the effects of race, class, and sex on six values. There may be a number of values other than these, however, the following conclusions can be reached relating to the six values examined.

1. Race appears to be a determiner of values in some cases, but in other cases it does not seem to be influential.

2. Social class does not appear to be an important determiner of values.

3. Sex appears to be a determinant of values in some cases, but in other cases it is not an important factor. 
4. It appears that the differences within the races and classes are greater than the differences between the races and classes. As far as values are concerned, there is a large area of homogeneity between the races, classes and sexes.

\section{Implications}

As has been pointed out, this study has some limitations. Nevertheless, some implications which are borne out by previous studies arise:

1. Social classes seem to have similar values. It may be that social class is not a major determinant of values.

This would seem to imply that members of the lower, middle and upper classes have correspondingly similar values, hence no need to change values of any social class, but to rather build on the strength of their similarities.

Educational theorists may have to modify their beliefs regarding the differences between children. It may be inadvisable for compensatory educationists to attempt to change the values of underprivileged children until this topic has been further researched.

2. There are some differences in values between the races, but the similarities between them greatly outweigh the differences between them.

In other words, blacks and whites have values which are more alike than are different. This similarity is something on which educational psychologists may build rather than seek to change. 
3. In many cases, sex is not an important factor in determining values.

Boys and girls have values which are very :zuch alike. Differences arise in the primary sense that individuals differ from one another. Such similarities seem to indicate that, as far as values are concerned, girls need not be treated differently than boys.

This study seems to indicate that social classes, races, and sexes, per se, are not always important determiners of human values. Children from all social classes, races and sexes are rather similar. Such an appreciation of the similarity of children should make teachers treat all pupils with the respect and dignity that they deserve. No child need be humiliated or treated with contempt because he comes from a different social background, race, or sex. Human beings are much more alike than they are different! 
B I B L I O G R A P H Y 
Allport, Gordon W., Vernon, P. E., Lindzey, G. Study of Values. 3rd edition. Boston: Houghton Mifflin Company, 1960.

Baldwin, James. The Fire Next Time. New York: Dial Press, 1963.

Clark, Kenneth B. and Clark, M. K. "The Development of Consciousness of Self and the Emergence of Racial Identification in Negro Preschool. Children." Journal of Social Psychology, 1957, $9,10,591-599$.

Coleman, James. Equality of Educational Opportunity. Washington, D.C.: HEW, USOE, 1966.

Crow, Edwin L., et al, Statistical Manual. New York: Dover Publications, 1960 .

Davis, Allison and Havighuret, R. "Social C1ass and Color Differences in Child-Rearing." American Sociological Review, 1946, II, 698-710。

Dyer, Helen C. Race and Intelligence: An Evaluation. New York: Anti-Defamation League of B'nai B'rith, 1963.

Gordon, Ira J. Human Development. New York: Harper and Row, Publishers, 1969.

Havighurst, Robert. "How Moral Life is Formed." Religious Education, $1962,57,432-439$.

Ha1l, Everett W. What is Value? New York: The Humanistic Press, Inc., 1952.

Klinger, Robert B. and Veroff, Julian. "Cross-Cultural Dimensions in Expressed Moral Values." Personality and Guidance Journal, 1964, 42, 899-903.

Lott, Albert J. and Lott, Bernice E. Negro and White Youth: A Psychological Study in a Border-State Community. New York: Holt, Rinehart and Winston, Inc., 1963.

Maslow, Abraham J. New knowledge in Human Values. New York: Harper and Row Fublishers, 1959. 
McCandless, Boyd R. Children and Adolescents: Behavior and Development. New York: Holt, Rinehart and Winston, Inc., 1961.

McGee, W. Values, Ethics and Behavior. Presentation at National Training Conference on Extension of Education in Family Life, Merrill Palmer Institute, September, 1963.

Montagu, Ashley. The Direction of Human Development. New York: Harper and Brothers, 1955.

Munat, Charles E. "Four, Poor, Non-White and Out-of-Sight." In Education of the Disadvantaged Edited by Joel L. Frost and Glenn R. Hawkes. 2nd ed. Boston: Houghton Mifflin Company, 1970 .

Parilla, Lenoa. "A Comparison of Values of Black and White Children in Lower Socio-Economic Class." Unpublished Master's Degree Project. Andrews University, 1971.

Perry, Ralph Barton. General Theory of Values. Cambridge: Harvard University Press, 1950. - Realms of Value. New York: Greenwood Press, 1968.

Pettigrew, Thomas F. A Profile of the American Negro. Princeton: D. Van Nostrand Co., Inc., 1964.

Raths, Louis E., et al. Values and Teaching. Columbus: Charles E. Merri11 Books, Inc., 1966.

Rettig, S. and Pasamanick, B. "Moral Value Structure and Social Class," Sociometry, 1961, 24, 21-35.

Rowland, Monroe K. and Delcampo, Phillip. "The Values of the EduCational Disadvantaged: How Different Are They?" Journal of Negro Education, $1968,37,86-89$.

Shuster, Jeannette W. "The Values of Negro and Caucasian Children: Do They Differ?" Journal of Negro Education, 1968, 37, 90-93.

Smith, Marshall S. and Bisse1, Joan S. "A Report Analysis: The Impact of Head Start." Harvard Educational Review. Vol. 40, No. 1, 1970, pp. 51-104.

Somner, Robert and Killian, Lewis M. "Areas of Value Differences I. A Method of Investigation. II. Negro-White Relations." Journal of Social Psychology, 1954, 39, 227-235, 237-244.

Warner, w. Lloyd. Social Class in America. New York: Harper and Row, Inc., 1960. 

A P P E N D I C E S 
APPENDIX A

This appendix contains the letter to Rowland requesting information regarding the reliability of the instrument he used. 
P.0. Iox 123

findrers University

Eerrion Springs, iI 49104

Ipril 3, 1972

Dr. Honroe Rowiand

Lssociate irofesson of Eüucation

San Diceo State College

San Dicê, Celifomia 92101

Dear Dr. Rovilana:

I am a lijgexian (West African) student working on a Haster's Degree at fndrers University in tho Depertrent of Houcation, vith an emphasis in psycholon. I atr wovling on a thesis comparing values of blacks and Caucasians of tho louer, niddle and upper socio-econonic levels. This would be a follow-up study of iijs Lenoa. Penrilla's earlier studies which were limited to tho lower socto-economio level only.

I would appreciate it if you would please allow me to use the Elenentary School Stridy of Values which you heve devoloped and which iiss Parrilia used for her suadies.

I would also appreciate it very much if you vould please explain how the constitidit or perheips concurrent validity of .80 was obtained as stated by Rowland and Del Campo, Joumal of liegro Education, 1968, page 87. It is very inportant that I lnow how this validity of .00 was obtained becauke that information will belp mo in the defense of my thesis.

Thank you very moch for your help.

Sincerely yours,

Emanuel 0la stolazbe 
APPENDIX B

This appendix contains the Elementary School Study of Values. 
DTRECIIONS

Co the next five pages are thirty pairs of things you might like to do. In each case you have three folnts to reul wisch of the pain you tould rather do.

1. If you like (a) much more thas (D) use the three points Lita this:

2. If you like (a) slightly wrere than (D) use the three polnts lice this:

3. If you like (b) slightly more than (a) use thie three points like this:

4. If you Like (b) much wore than (a) use the three points like this:

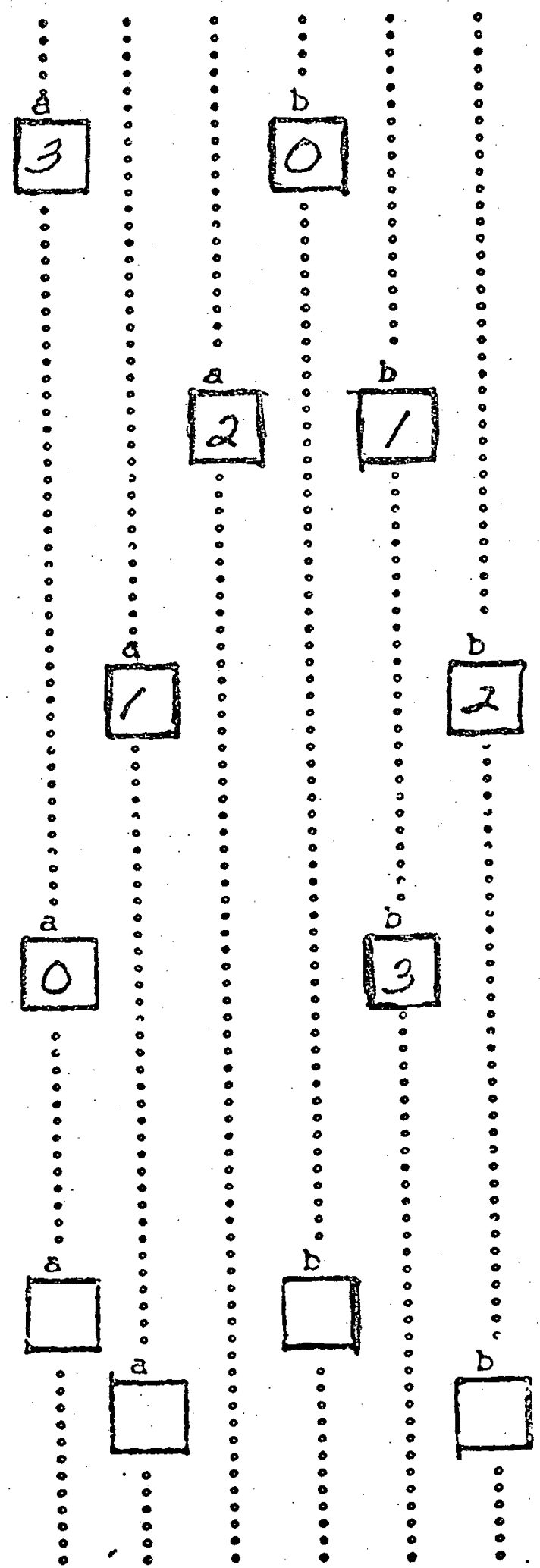

PRACTICE CHOICES: WORD YOU RATHER . .

2. a. ear your favorite food, os b. be punistied?

2. a. be uninappy, or b. be happy? 
WOULD YOU RATHER . .

do a. paint a picture, or

b. Jook at things through a microscope?

2. a. own new toys, or

b. De in a churnch chair?

3. A. Bee that everyone on a team is given a chance, or

D. Win a gome?

4. a. read a religjous story, or

b. solve a number puzzle?

5. s. Join a musical group, or

b. have lots of playthings?

6. a. Ihink abour how to make other people do the thirgs you thi-k are right, on b. watch a TV shaw about religion?

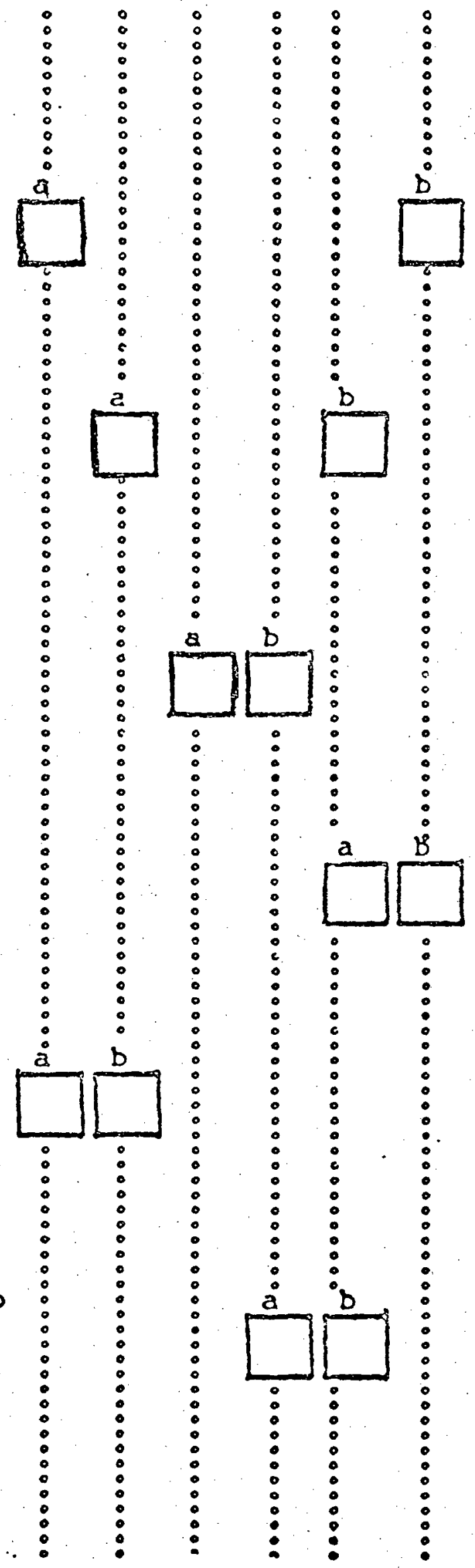


WOULD YOU RATHER. . .

7. A. Live in a big house, or

D. help a friend who can't do his stucies?

8. 8. be left in charge of the class when the reacher is out, or

b. have someane explain what makes soinething work?

9. a. Fead about someone who helps others, or b. say grace at the dinner tuble?

20. A. have an allonzance, or b. be captain of a tean?

21. a. make your roon look nice, or D. be thoughtful of others?

12. a. take care of your becks, on b. put new ideas together?

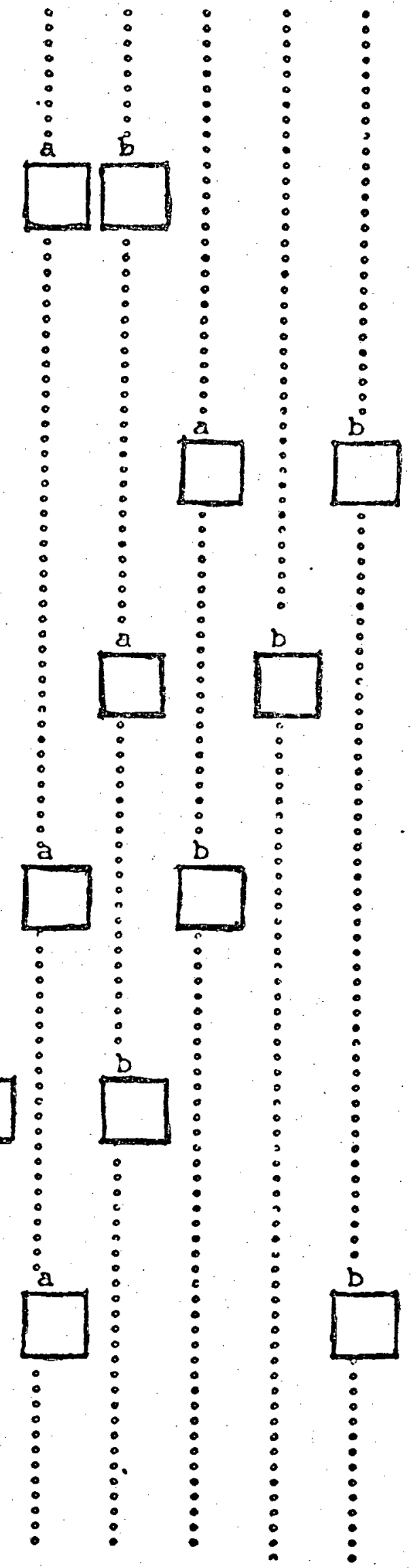


GOUID YOU RATHER . .

23. a. hike along a creek, or b. think of God?

24. a. do the dishes for your mother, or D. use a ruler to find out how bis things ane?

25. B. sing, or

D. win an argument?

\section{$A E S P R$}
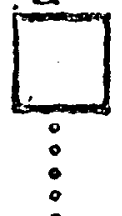

$:$

(1) 
WDISD YOU RATEER . .

20. a. be a scientist, or

i. be a norker in the church?

20. 2. de confortatly eressed, ar Do be nicaly dressed?

21. Q. 80 to Sunday Schoel, or

b. make other people do the right thing?

22. 8. take care of soweone who has been hure, or

3. b. make maney?

23. A. read about new discoveries, of b. be a leader?

24. a. say your frayers, or

b. share your lunch with soneone else?

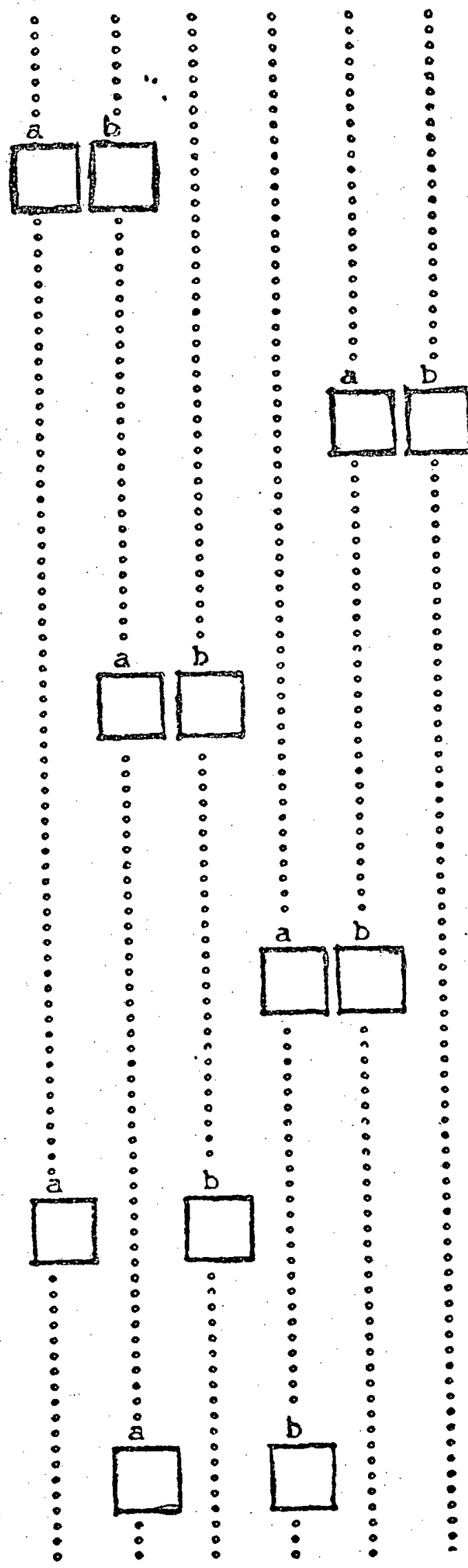


COUID TOU RATIER . .

25. 8. wir an election or

b. have your father wake lots of mey?

25. D. watch a TV stow abour people who help other people, or

D. alce things out of clay?

27. a. think about questions that don't have ansters, or

b. have a bank account?

28.. a. Listen to someone read from a religious boak, or

b. visir an art galiery?

23. a. study science, or

b. be a numse or a doctor?

30. a. be President, ab

b. be an artist?

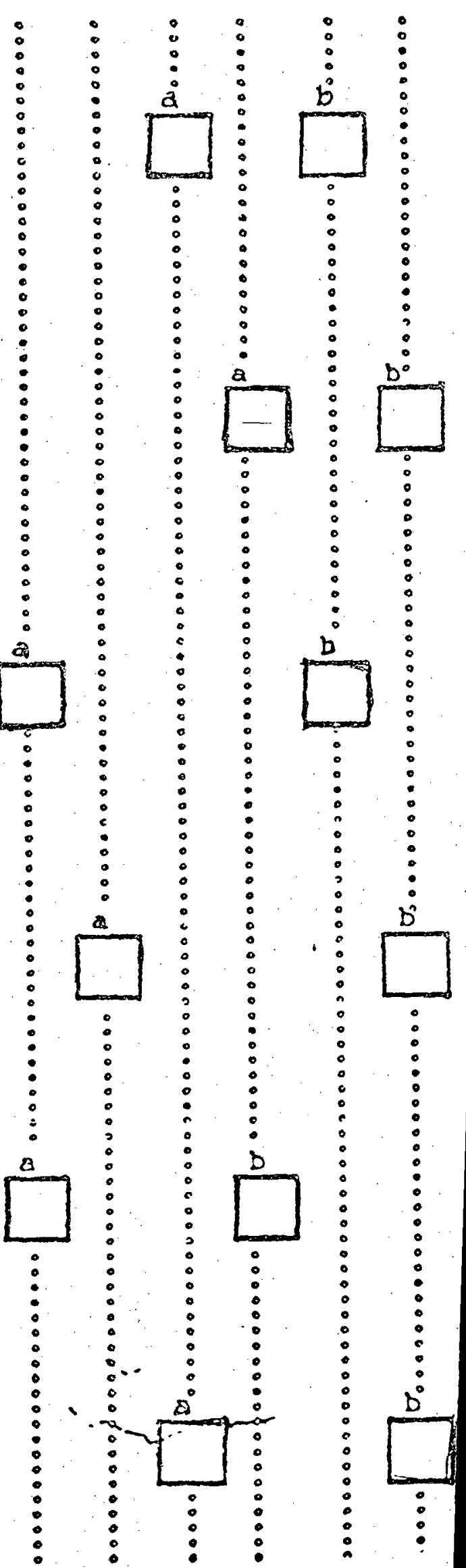


APPENDIX C

This appendix contains the raw data obtained in the present study. 
RAW SCORES FOR THE AESTHETIC VALUE

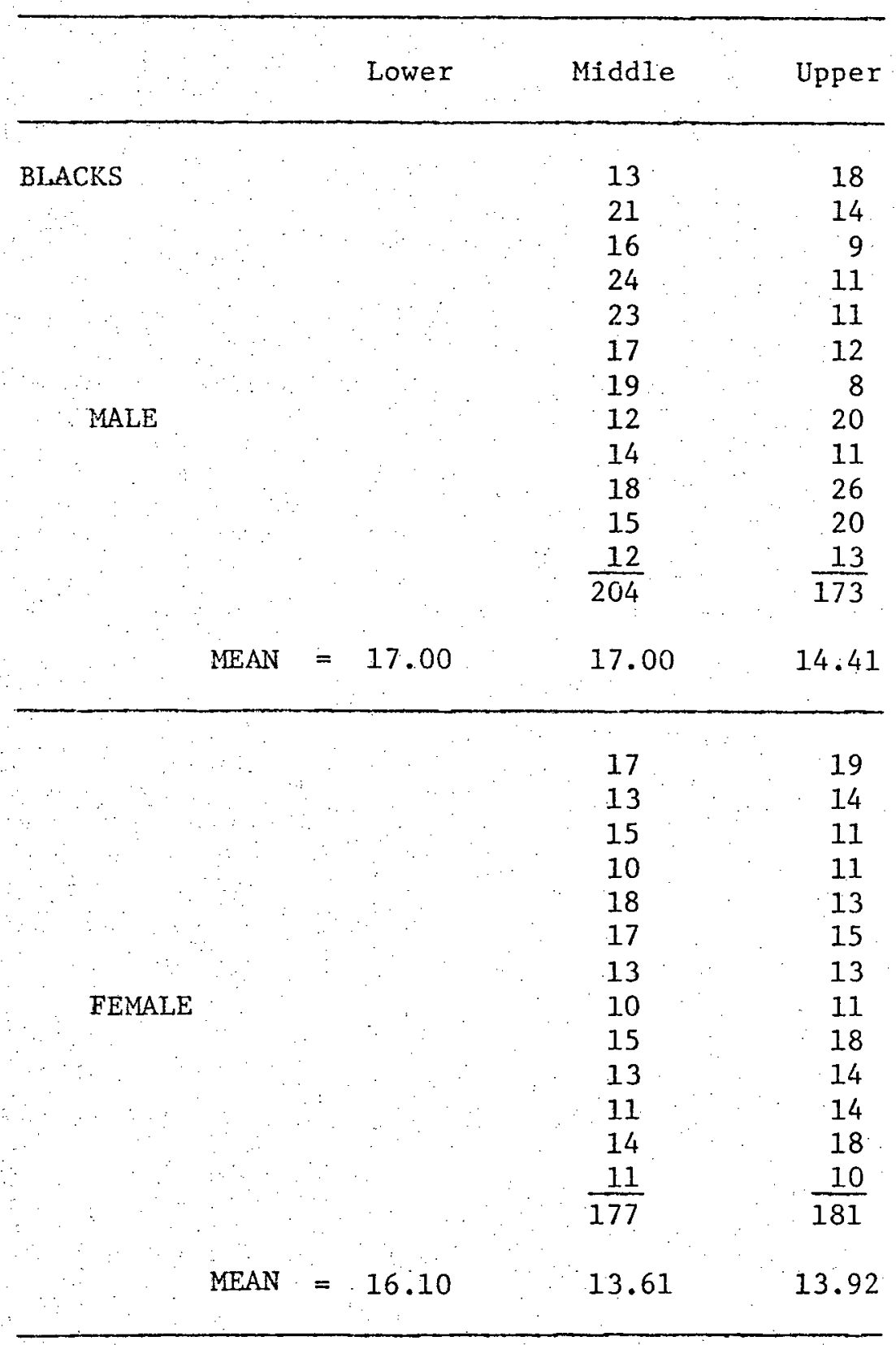


RAW SCORES FOR THE AESTHETIC VALUE (CONTINUED)

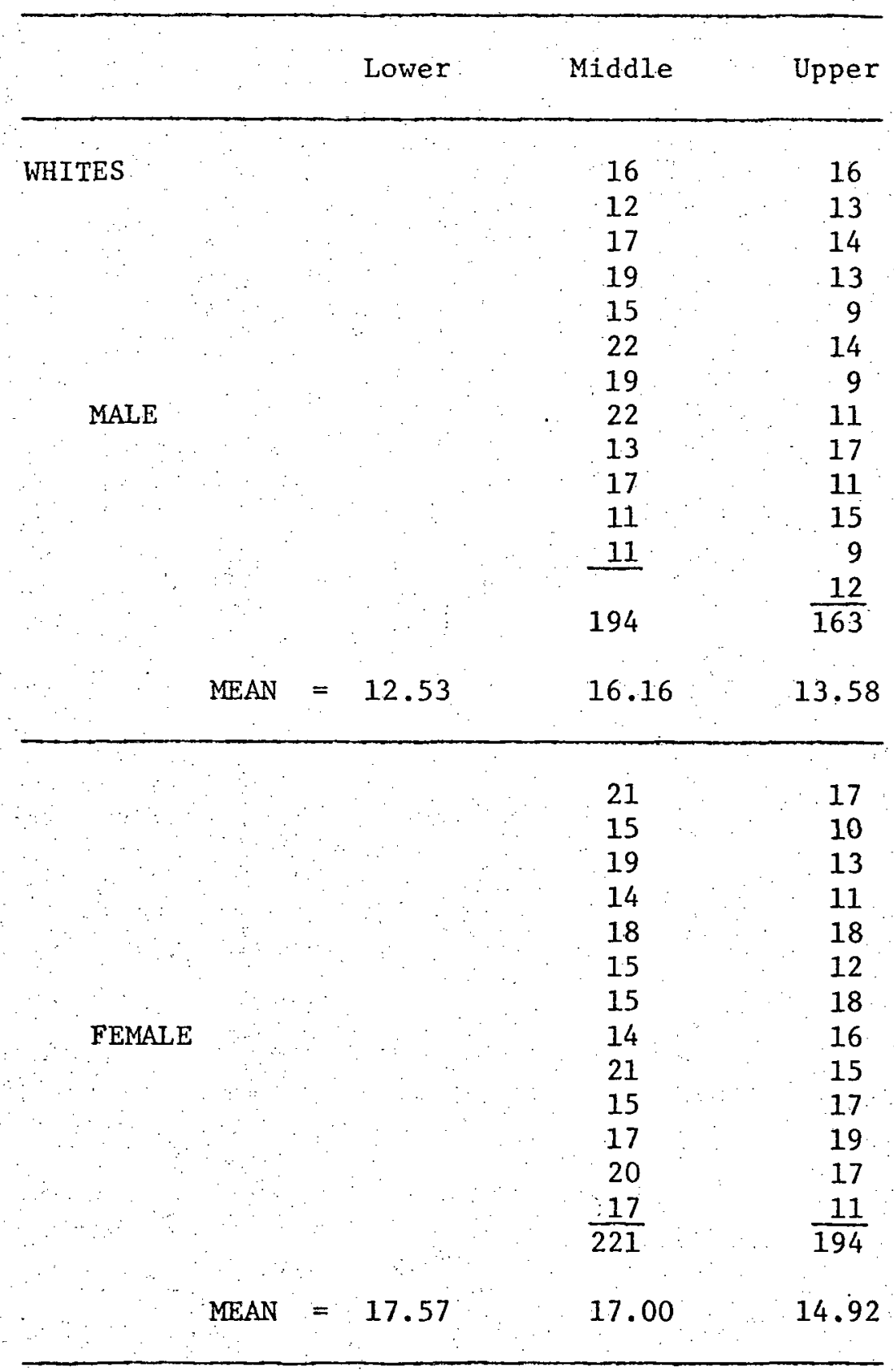


RAW SCORES FOR THE ECONOMIC VALUE

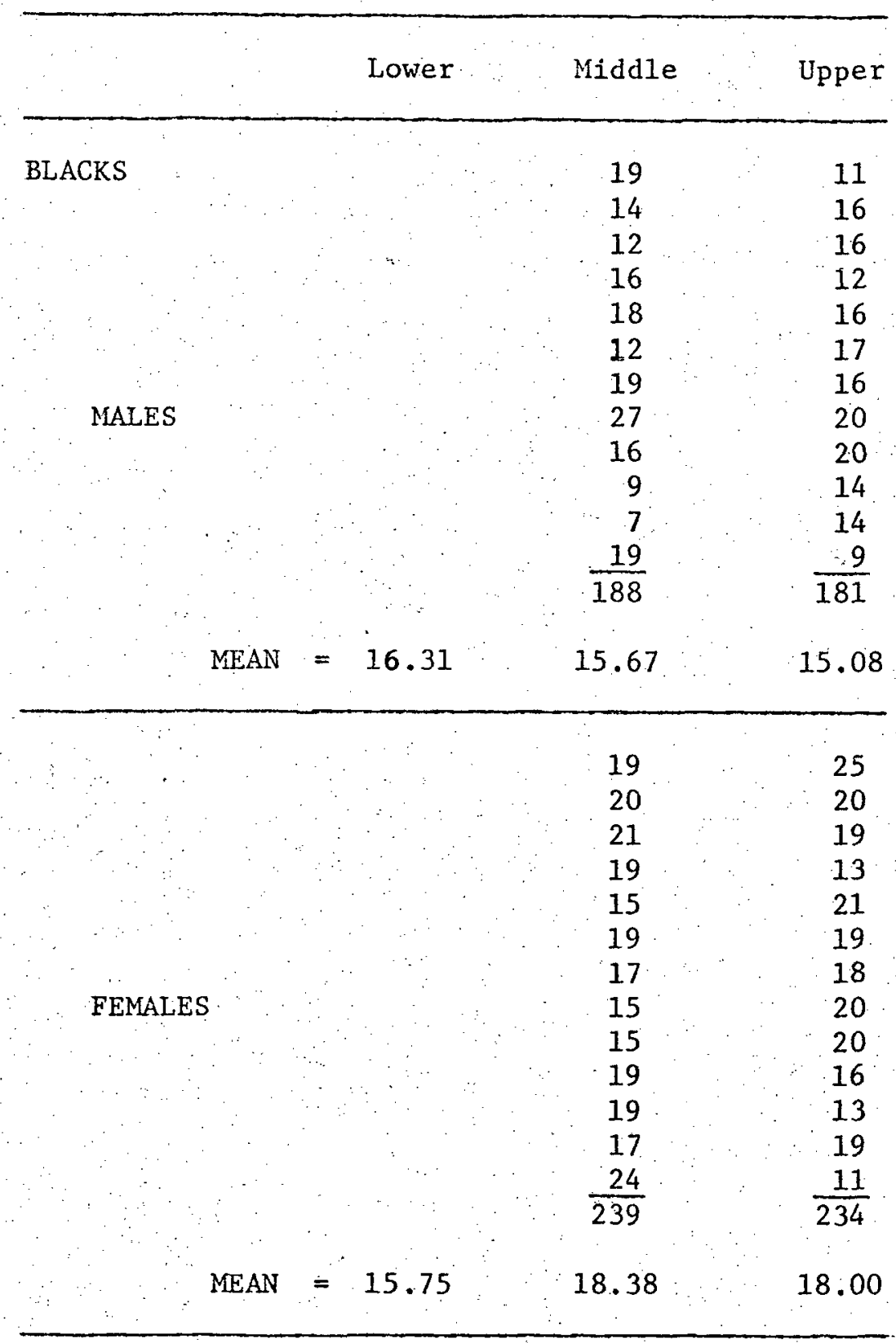


RAW SCORES FOR THE ECONOMIC VALUE: (CONTINUED)

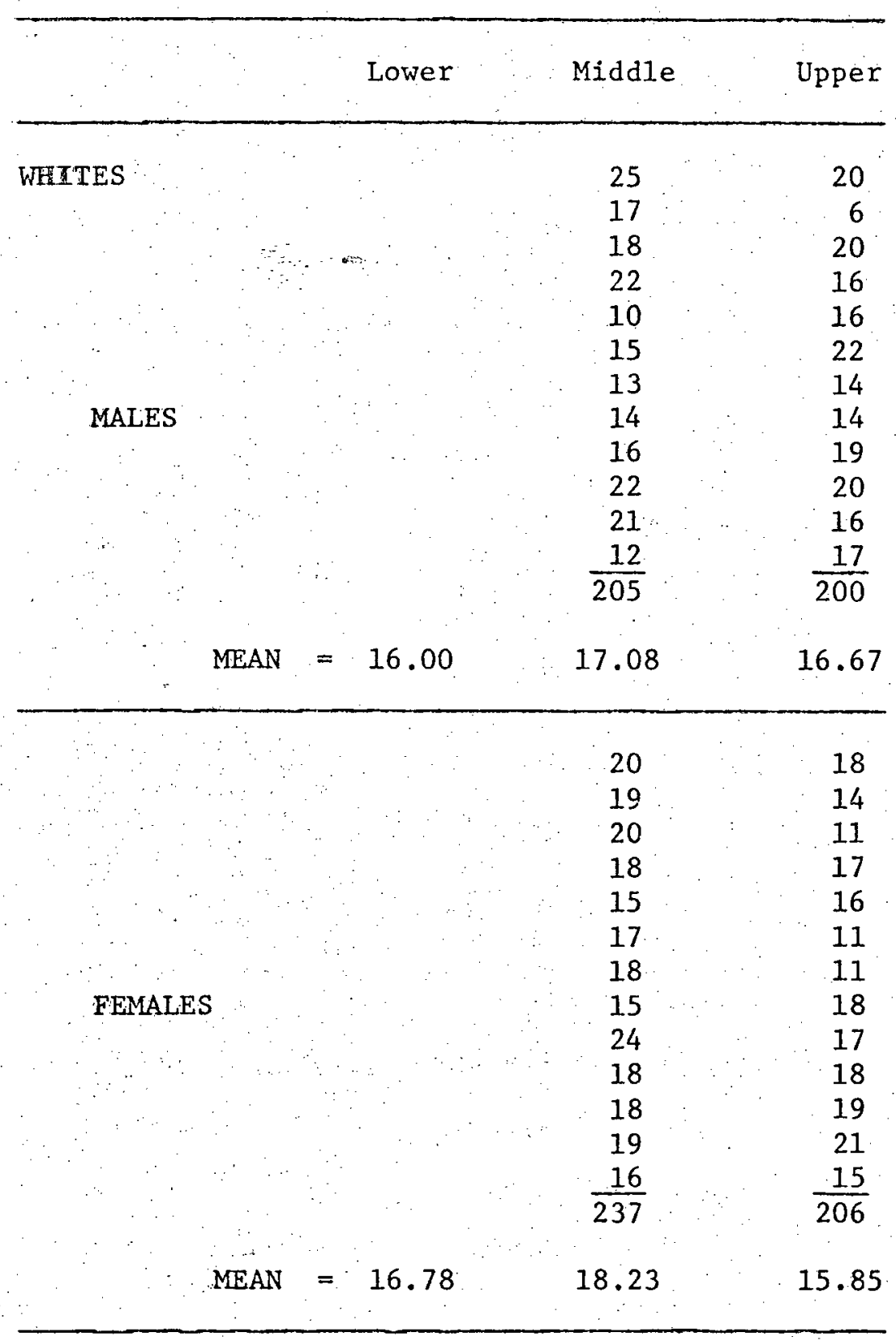


RAW SCORES FOR THE SOCIAL VALUE

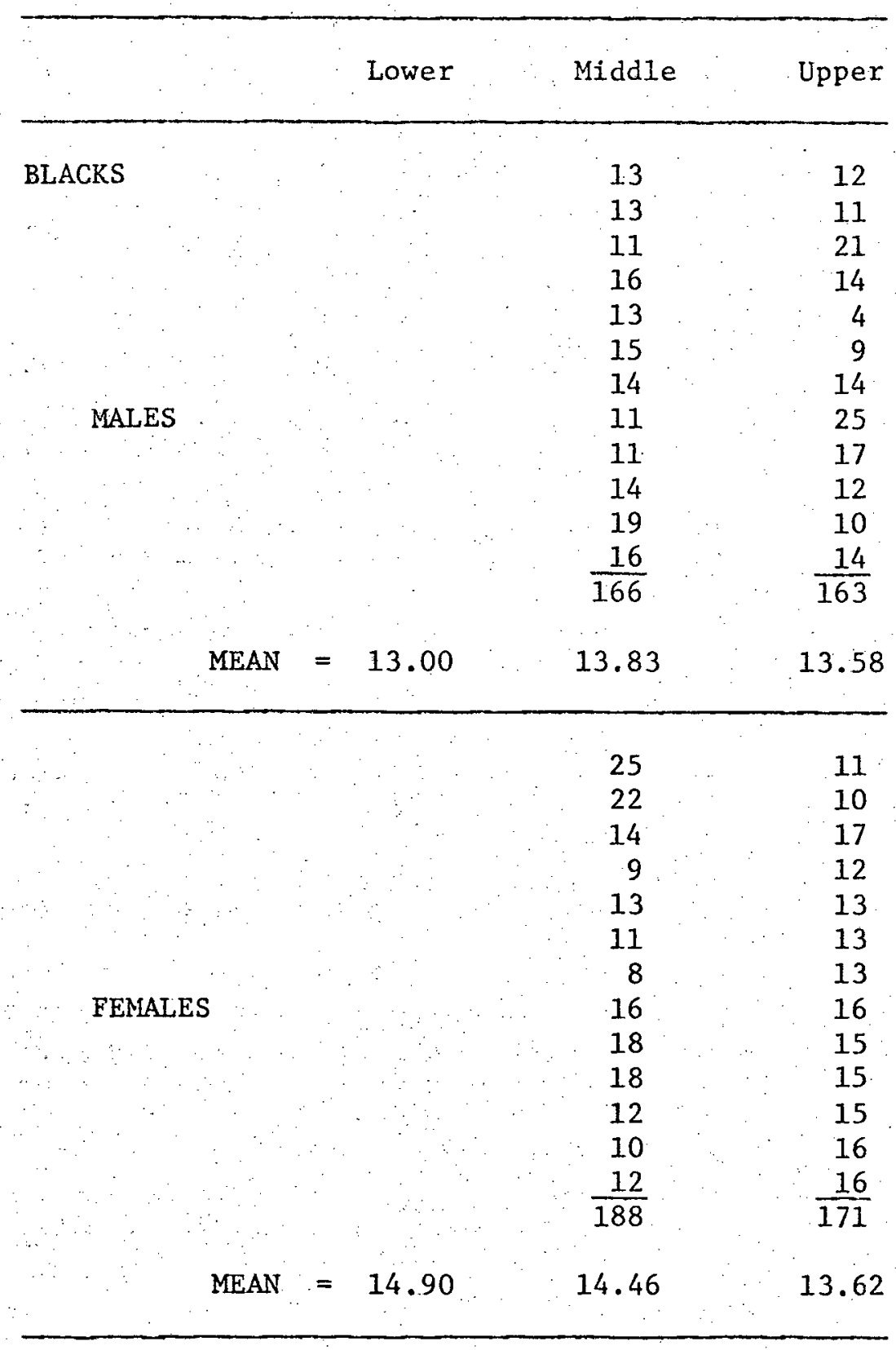


RAW SCORES FOR THE SOCIAL VALUE (CONTINUED)

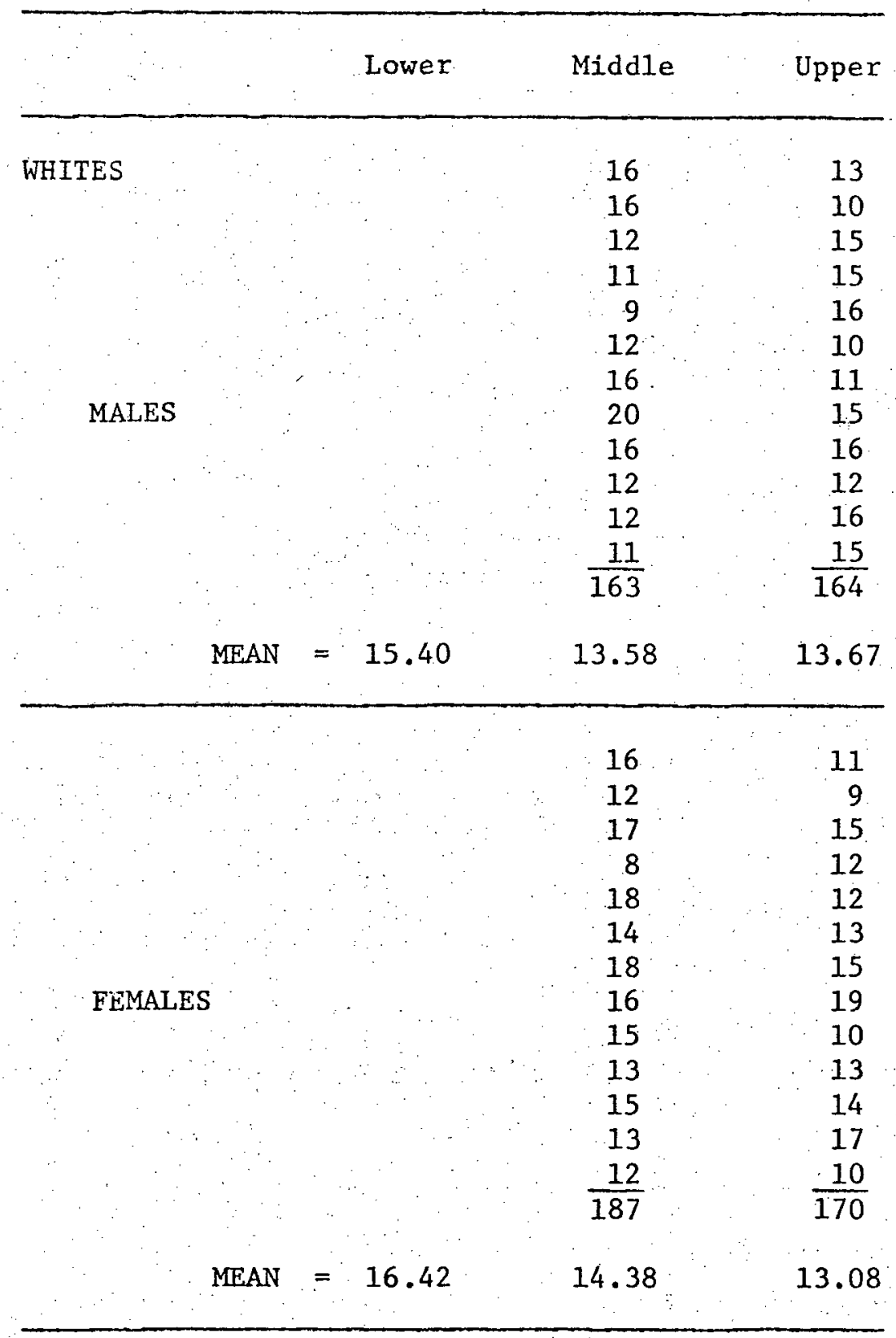


RAW SCORES FOR THE POLITICAL VALUE

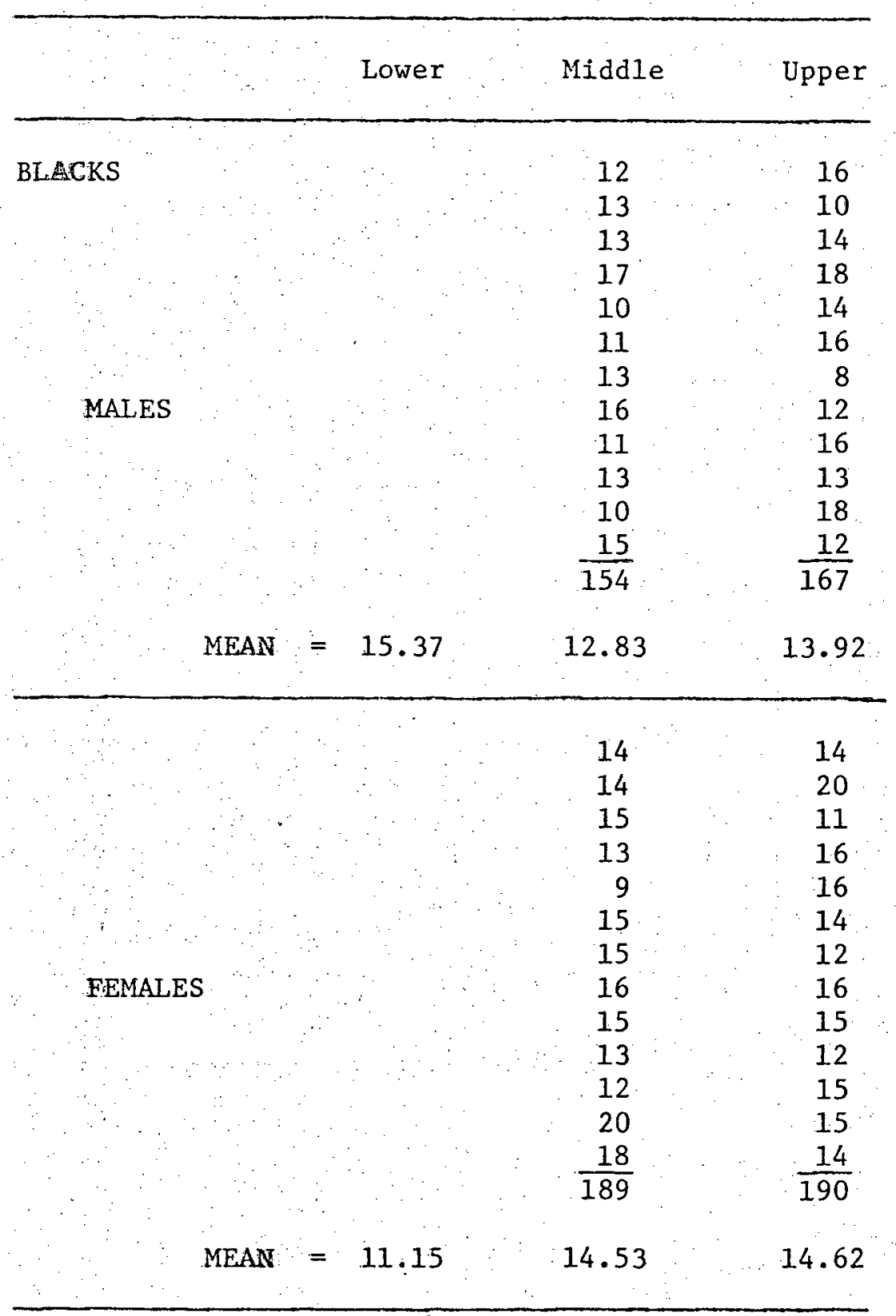


RAW SCORES FOR THE POLITICAL VALUE (CONTINUED)

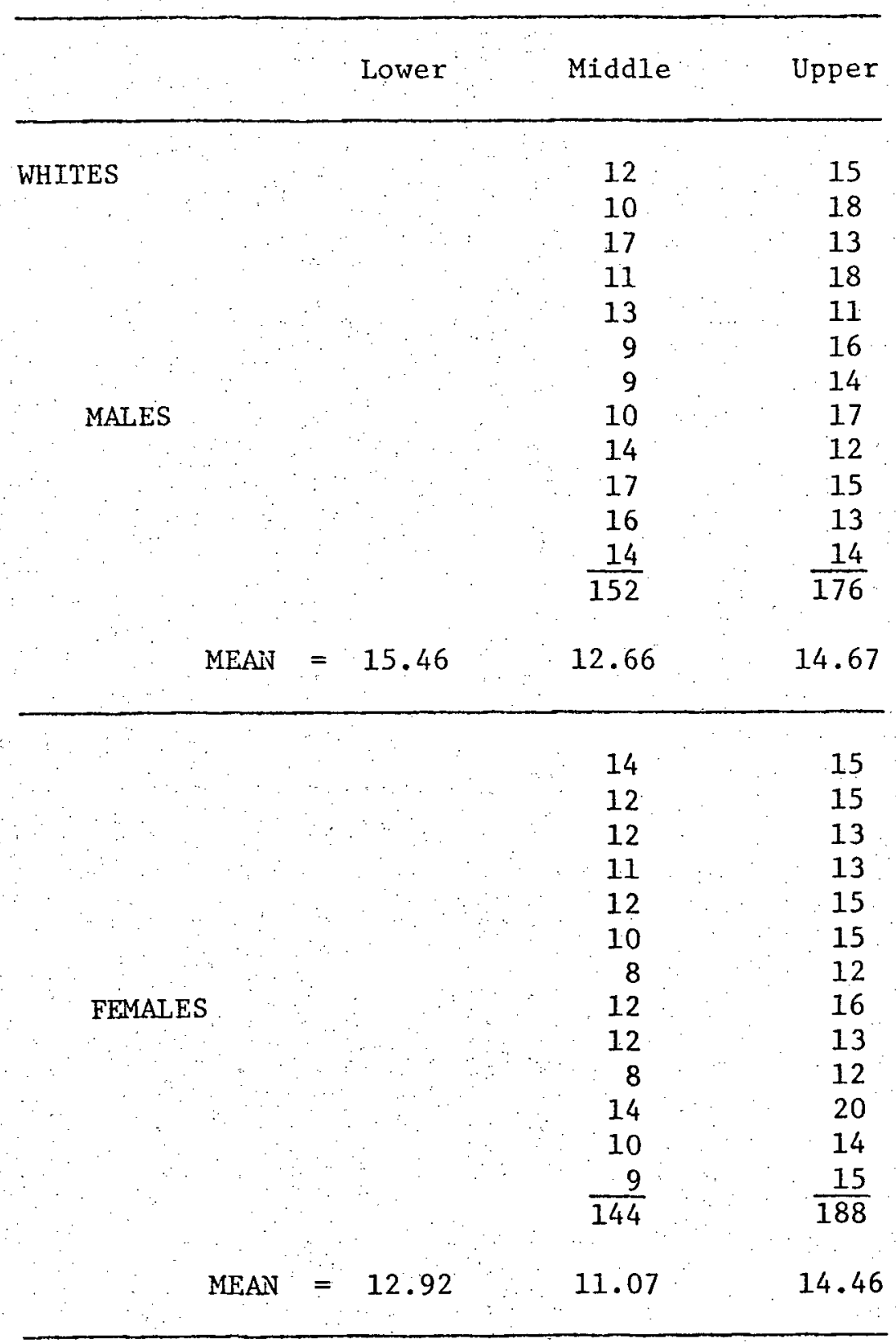


RAW SCORES FOR THE RELIGIOUS VALUE

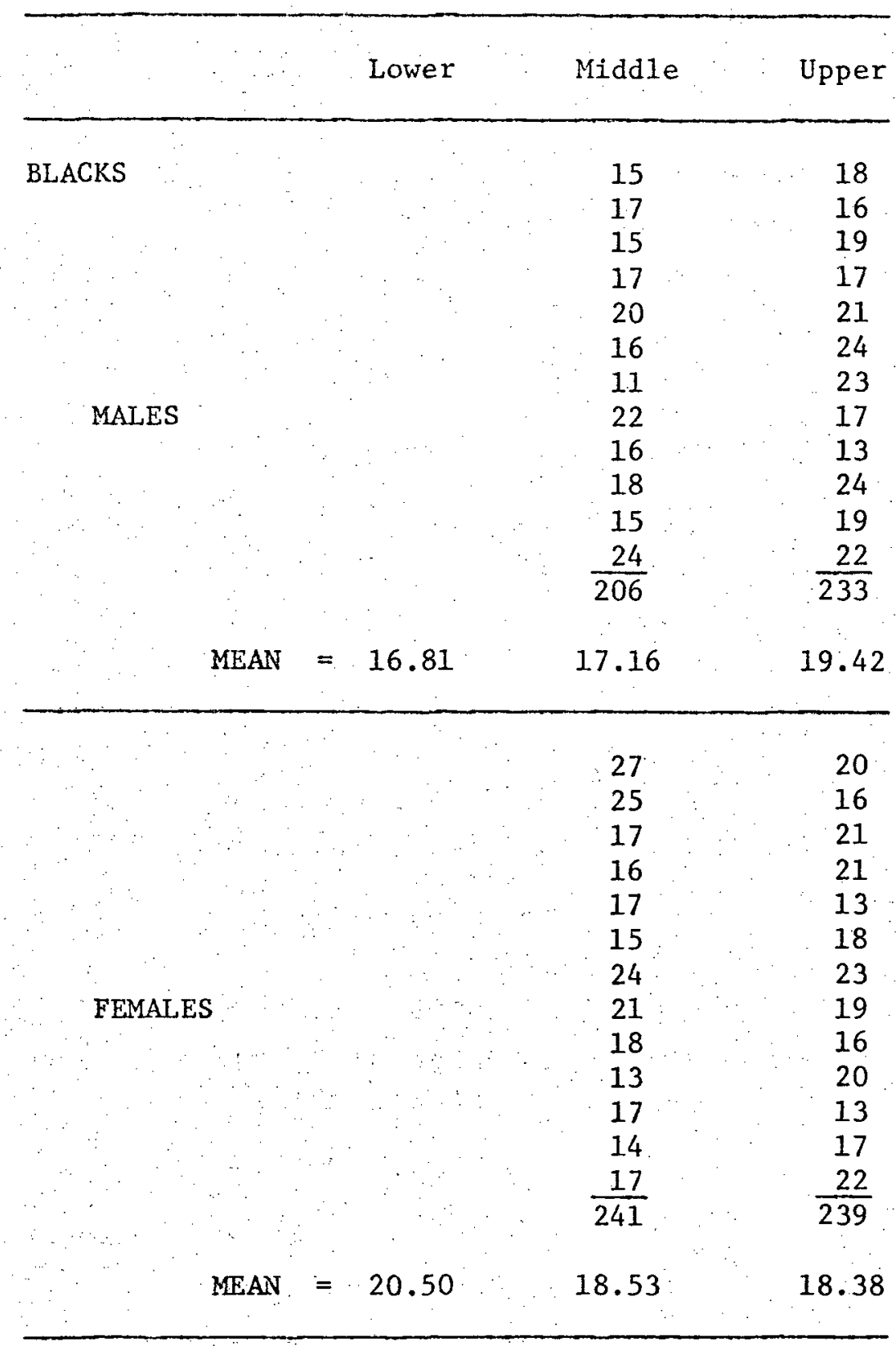


RAW SCORES FOR THE RELIGIOUS VALUE (CONTINUED)

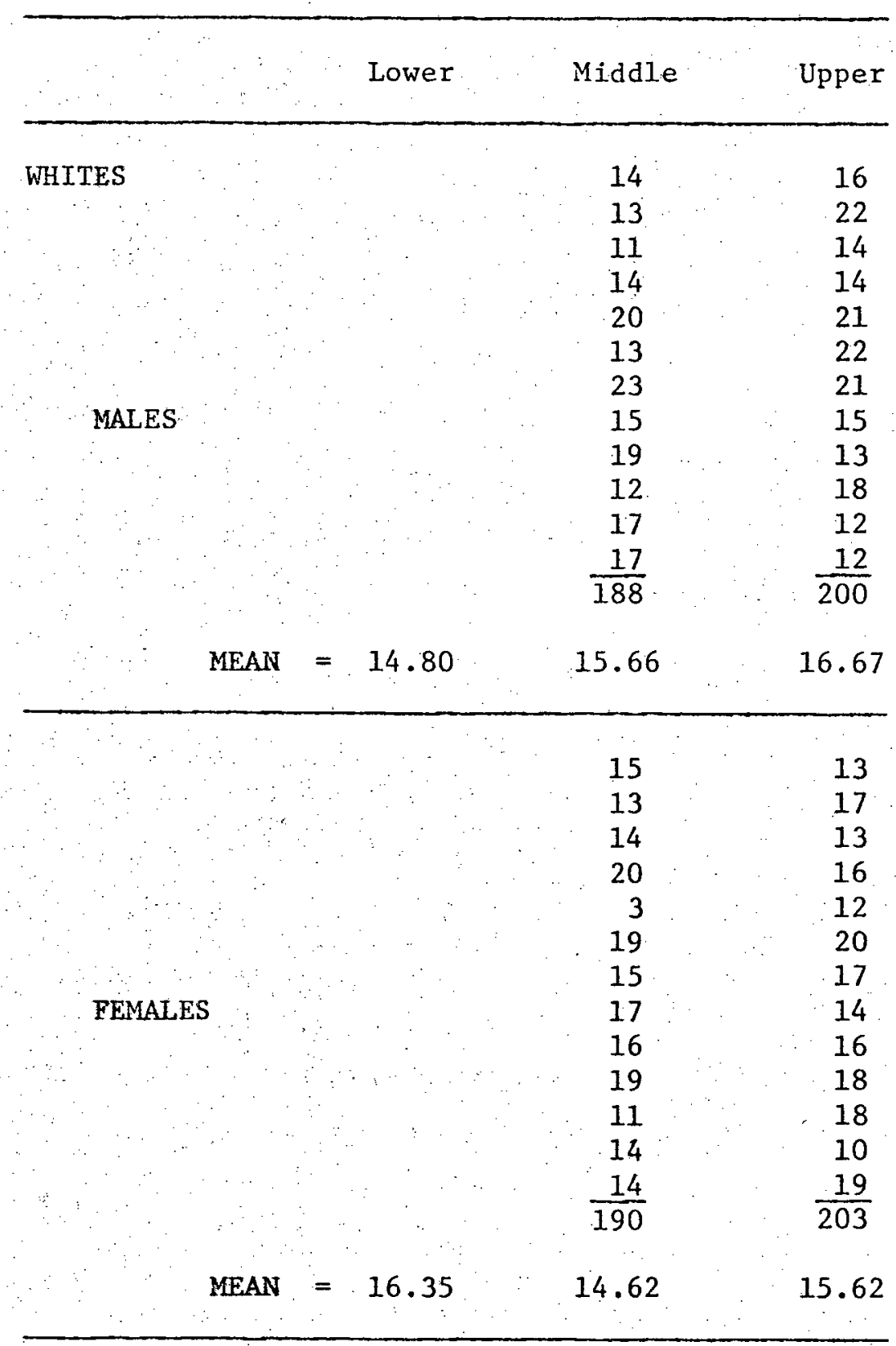


RAW SCORES FOR THE THEORETICAL VALUE

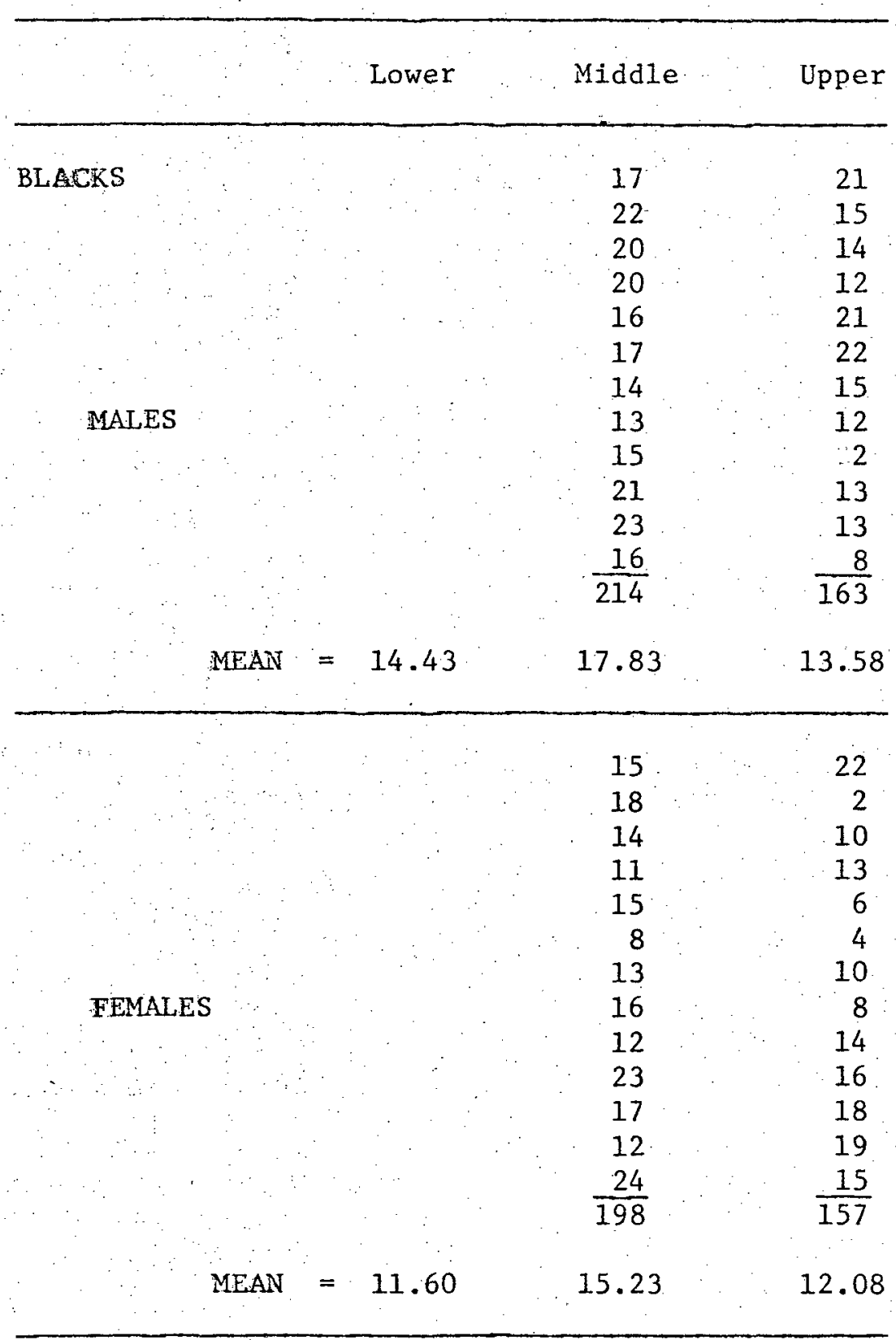


RAW SCORES FOR THE THEORETICAL VALUE (CONTINUED)

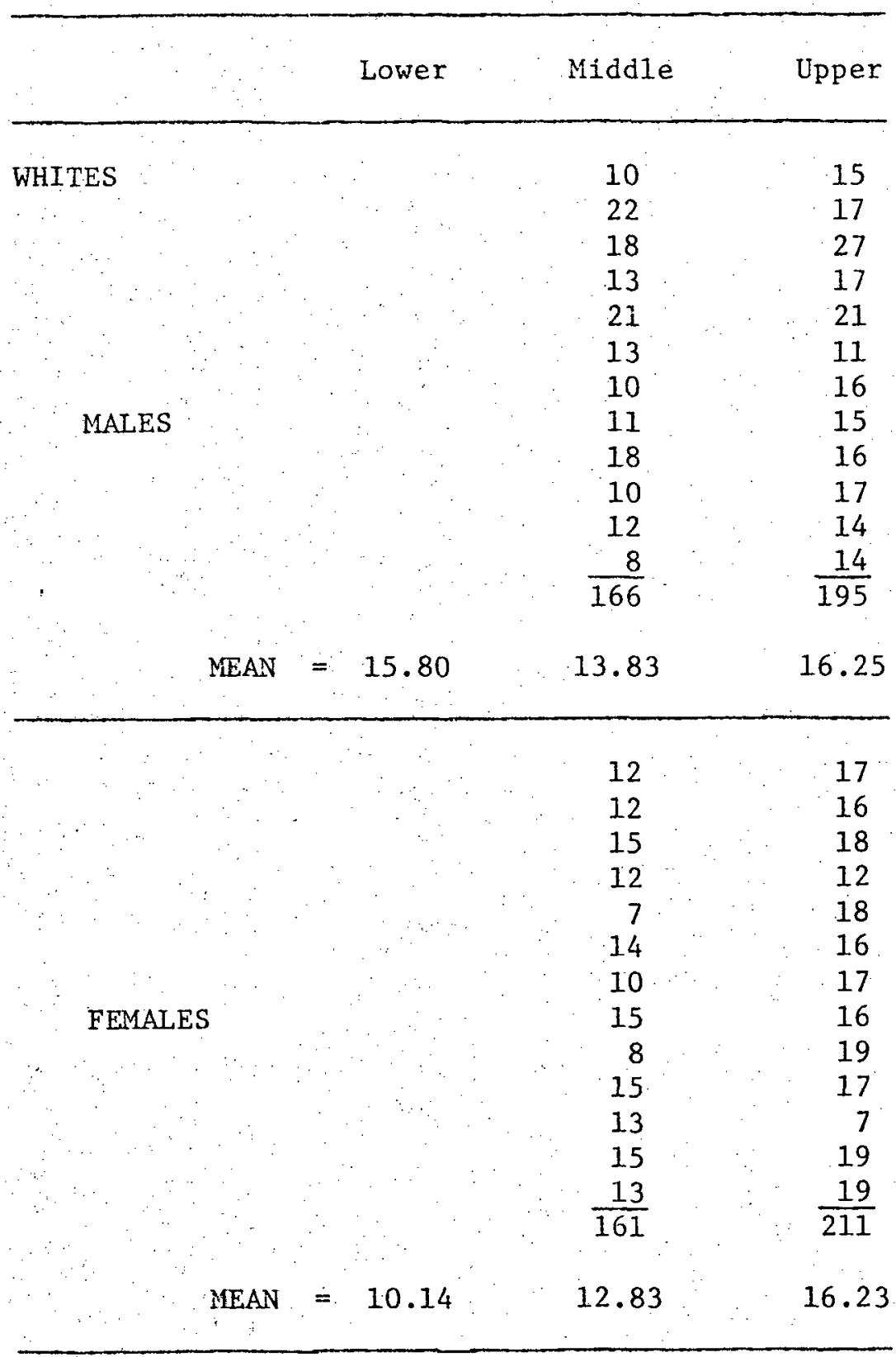

